\title{
NEW FRAGMENTS OF GILGAMEŠ AND OTHER LITERARY TEXTS FROM KUYUNJIK
}

\author{
By E. JIMÉNEZ
}

The public availability of photographs of the entire British Museum Kuyunjik collection has allowed the identification of many hitherto unplaced fragments. Some of them are particularly relevant for the reconstruction of passages in a number of ancient Mesopotamian literary texts. These are published here for the first time. They include three new fragments of the Gilgame ̌s epic, one or two of the Theodicy, several of the Diviner's Manual and of the Rituals of the Diviner, several prayers previously only poorly known, and fragments from the seventh tablet of the exorcistic series Muššu u.

Ashurbanipal's libraries represent the single most important collection of literary tablets from first millennium Mesopotamia, and they will continue to do so for the foreseeable future. Almost all genres are represented within them, and the reliability and legibility of their manuscripts have proven an invaluable touchstone when confronted with duplicates from different cities and periods. Despite the intensive work of several generations of scholars, their wealth is far from exhausted, and many of their texts still remain unpublished and many of the fragments unidentified. This makes the possibility of accessing the entirety of their contents at the click of a button, via the British Museum's online database of photographs, ${ }^{1}$ particularly welcome news for the student of Babylonian literature. Such a resource has allowed the identification of many hitherto unplaced small fragments, a selection of which is published here by the kind permission of the Trustees of the British Museum. ${ }^{2}$

\section{Finish Humbaba! (Gilgameš V 195-206 = 264-74)}

In the fifth tablet of the Standard Babylonian version of Gilgameš, Humbaba, overpowered by Gilgameš with the help of Šamašs fierce tempests (SB Gilg V 160-66), ${ }^{3}$ pleads with his captor for his life. Enkidu, however, counters Humbaba's pleas in a series of speeches which, together with Humbaba's rejoinders, occupy more than one hundred verses (11. 167-284). This dialogue, in which Enkidu addresses Gilgameš, and Humbaba begs alternately Gilgameš and Enkidu, concludes with Humbaba's defeat and his subsequent beheading (11. 285-90).

The small fragment Sm.209 (fig. 1) preserves part of one of Enkidu's speeches from this episode. It belongs most likely to the fourth or fifth column of the same tablet as K.3252+ $\left(\mathrm{MS} \mathrm{H}_{1}\right.$, George 2003: pls. 72-73) and K.8591 (MS $\mathrm{H}_{2}$, olim MS AA, George 2003: pl. 70 and al-Rawi \& George 2014: 73), and could therefore be termed $\mathrm{H}_{3}$. The speech of Enkidu in question is repeated twice in the preserved text of Gilgameš V (11. 196-204=266-72), ${ }^{4}$ and the fragment could conceivably belong to either occasion.

\footnotetext{
${ }^{1}$ At http://www.britishmuseum.org/research/collection online/search.aspx. Geers' copies of tablets mainly from the Kuyunjik collection are also now publicly available at http://cdli.ucla.edu/?q=downloads.

${ }^{2}$ Thanks are expressed A.R. George for providing a plausible placement of text no. 1, and for his comments on texts nos. 2-3. The participants of the Yale cuneiform reading group made many useful remarks on text no. 6. Prof. B.R. Foster, M. Frazer, and U.S. Koch read the manuscript carefully and provided many valuable
}

suggestions. All remaining mistakes are the author's sole responsibility.

The line numbering follows the revised numbering for Gilgameš V, established by F.N.H. al-Rawi and A.R. George in the light of a new manuscript now in the Suleimaniyah Museum (= MS ff, edited by al-Rawi \& George 2014).

${ }^{4}$ It is feasible that it could be repeated more times, since an important portion of the disputation between Enkidu and Humbaba (11. 207-246) is still missing. 
$195=264 .[0$ o o $] \times[\ldots]$

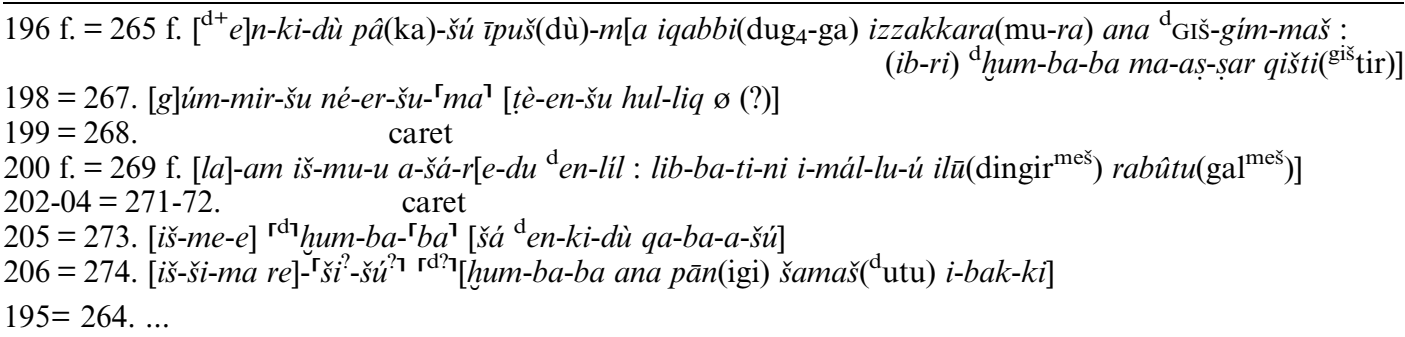

$196 \mathrm{f} .=265$ f. [Enk]idu made ready to speak [and said, addressing Gilgameš:

$198=267$. "[F]inish him, slay him, [destroy his power]!

"(My friend), Humbaba, the guardian of the forest], $200 \mathrm{f}$. $=269$ f. "Before [Enlil], the forem[ost], learns about it [and the great gods become enraged with us.]" $205=273$. Humbaba [listened to Enkidu's speech],

$206=274$. [Humbaba raised] his [head, weeping before Šamaš.]

Two unusual aspects of this fragment call for explanation, namely the co-occurrence of two almost contiguous doubled-up lines $(196 \mathrm{f} .=265 \mathrm{f}$. and $200 \mathrm{f} .=269$ f.) and the omission of several lines that are preserved in other manuscripts $(199=268$ and $202-04=271-72)$. The existence of two doubled-up lines in such a small fragment becomes explicable if one considers that doubled-up lines occur only in clusters elsewhere in MS H (e.g. Gilg V 29 f., 37 f., 39 f., 46 f.; and 95 f., 100 f., 104 f.). Secondly, the absence of some lines present in the duplicates can be attributed to recensional variation when the situation of other manuscripts is examined. Indeed, the omissions of 11. 268 and 271-72 in this fragment parallel that of 1. 268 in MS dd (Uruk), and of 11. 271-72 in MS ff (Babylonia). The Nineveh fragment, however, preserves the shortest known version of the speech. ${ }^{5}$

\section{The marshland and the reeds (Gilgameš VI 113-18)}

The sixth tablet of Gilgameš narrates Ištar's failed attempt to seduce Gilgameš, and the revenge undertaken by the rejected goddess: summoning the Bull of Heaven, she brings it to Uruk, where it wreaks havoc.

Sm.423 (fig. 2) joins K.15193+ (Q 3 , copied in George 2003: pl. 88), one of the three known Nineveh exemplars of SB Gilgameš VI, duplicating the lines where Anu accedes to Ištar's pleas and grants her the Bull of Heaven. It contains no new text, but confirms A.R. George's restoration of the Ninevite version of 1. 117:

113. [iš-me]- $-{ }^{\mathrm{\Gamma}} e^{\mathrm{T}}-m a \mathrm{~d} a-n u$ an-[na-a] ${ }^{\mathrm{\top}} q a^{\mathrm{T}}-[b a-a \mathrm{~d} i \check{s}-t a r]$

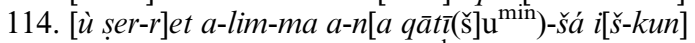

115. [o o (o)]-ma i-red-[da-á]šs-š́ d ${ }^{\mathrm{d}}[\grave{i s ̌-t a r}]$

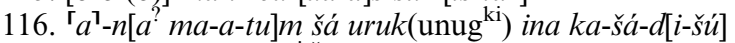

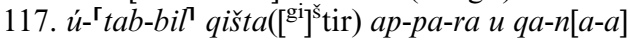

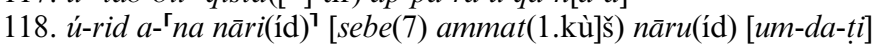

113. Anu [list]ened to this speech of [Ištar]

114. [then] p[ut the lead-ro]pe of the bull in her [ha]nds.

115. [Ištar departed], leading it on,

116. when [it] arrived in the [land] of Uruk,

117. it withered the forest, the marshland and the re[eds],

118. it went down to the river, the water level [dropped seven cubi]ts.

\footnotetext{
${ }^{5}$ On the various recensional differences in SB Gilgameš, see George 2003: 419-31, esp. 422 on type D manuscripts (to which this fragment probably belongs) and their recensional divergences with Late Babylonian manuscripts. As opposed
}

to the second occurrence of the speech (11. 266-72), which is preserved in two MSS (MSS dd and ff), the first one (11. 196204) is preserved only in MS dd, and it is therefore unknown if several versions of this speech too were in circulation. 


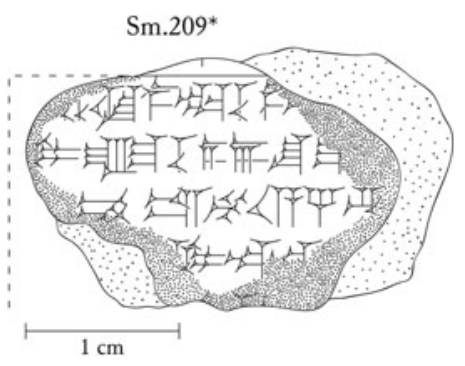

Fig. 1

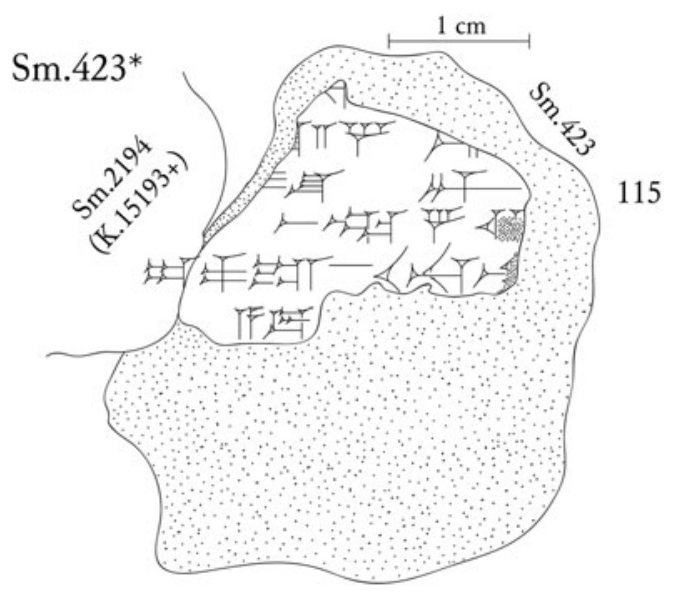

Fig. 2

\section{May she accept it! (Gilgameš VIII 135-42)}

A great part of the eighth tablet of Gilgameš consists of a list of chthonic deities whose favour Gilgameš seeks to win on behalf of his recently deceased friend, Enkidu. In a complex ritual, strongly reminiscent of funerary rites described in other Babylonian texts, Gilgameš displays an offering to each deity and beseeches that each in return welcome Enkidu into their realm.

The tiny fragment K.19751 (fig. 3) belongs to the end of the third column of one of the Kuyunjik manuscripts of Gilgameš VIII, MS V (K.8281(+) K.8565+ (+) K.8587(+) K.19549, copied in George 2003: pls. 102-03), and should therefore be termed $\mathrm{V}_{5}$. The lines preserved fall at the beginning of the funeral ceremony.

135. [ta-am-hi ${ }^{?}$-șu (?) kal-li-re-e iș-si] e[I]-l[im]

136. [a-na $\mathrm{d}$ iš-tar šar-ra-tum rabìtu(gal-tum) šamaš $\left.\left({ }^{\mathrm{d}} \mathrm{utu}\right) u\right] k$-tal-li[ $[\mathrm{m}]$

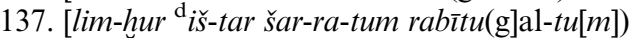

138. [a-na pān(igi) ib-ri-ia lu-ú ha-da-at-ma i-da-a-š́u lil-lik

139. [o o x-na-am o o o te]-di-qa

140. [a-na bēlet-ilī̄(dingir-mah) šarratu (?) rabītu(gal-tum) šamašs $\left.\left({ }^{\mathrm{d}} \mathrm{utu}\right) u k-t\right] a l-l i m$

141. [lim-hur bēlet-ilī(dingir-mah) šarratu (?)] rabìtu(' $\left.{ }^{\text {gal }}{ }^{-}-t u m\right)$

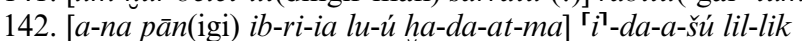

135. [A throwstick of ..., the pu]re [wood],

136. [for Ištar, the great queen, he] displayed it [to Šamaš]:

137. "[May Ištar, the] great [queen, accept this]!

138. [may she rejoice at my friend] and walk [at his side]!"

139. [... a dr]ess.

140. "[May she rejoice at my friend and] walk at [his side]!"

141. [For Bēlet-ilī], the great [queen, he disp]layed it [to Šamaš]: 
(a) K.19751*

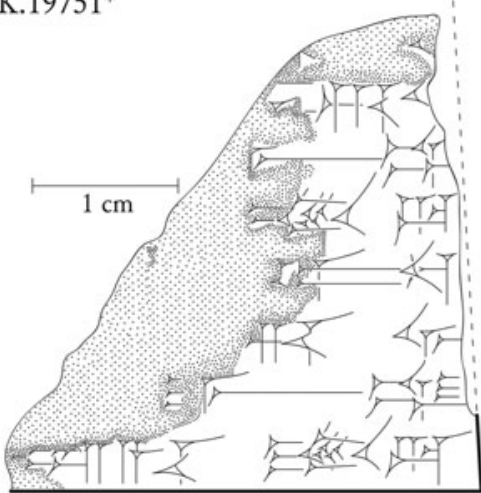

(b)

\section{BM 36909+}

140

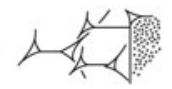

Fig. 3

142. "[May Bēlet-ilī], the great [queen, accept this]!

143. [May she rejoice at my friend and] walk at his side!"

The fragment suggests that the divinity invoked in $11.140 \mathrm{ff}$. is a feminine one, so the previous decipherment of the name as Ašim-babbar should be questioned. The only traces of the god name, preserved in BM 36909+ (MS m 1 , see I.L. Finkel's copy in George 2003: pl. 104), are probably to be read as [DING]IR.MA[H], i.e. Bêlet-ilī (see the adjoining copy in Fig. 3b). After the goddess's name, the epithet may have been the same one Ištar receives, viz. [šarratu] rabītu, which is Bēletili's sobriquet in a number of texts. ${ }^{6}$

Although Bēlet-ilī does not appear in any of the standard lists of Netherworld deities, Ninhursag, a goddess with similar functions, does occur among the chthonic gods in the Sumerian poem The Death of Gilgameř (see George 2003: 489-90).

4. The onager that nibbles the lushest grass (Theodicy 46-51)

In the Theodicy the sufferer questions the righteousness of divine judgment by presenting a series of situations where evil actions are rewarded, while fair behavior is punished. These situations, he argues, are not limited to the human world: animals are also ruled by this inverted moral law.

The line of reasoning of the sufferer can now be understood better thanks to the joining of K.17474 (fig. 4) to K.3452+ (MS C+ of Theodicy, copied in Lambert 1960 pl. 20 and 25), ${ }^{7}$ which restores the end of $1.48 .^{8}$ The text presented here is that of MS C+, restored by means of several published and unpublished duplicates:

48. [ak-ka-an-nu sír-ri-mu ša] it-pu-pu šu-muh šam- ${ }^{\top} m e^{\top}$

49. [ak-kab-ti-i pak-ki] ili(dingir-dingir) $\dot{u}$-zu-un-šú $i b$-ši

50. [ag-gu la-b]u šá i-tak-ka-lu du-muq [s] $]^{\top} i-i-r i{ }^{\top}$

51. [ak-ki-mil-t]i il-ti-i šup-țu-ri ú-bi[l maṣ-hat-su]

\footnotetext{
${ }^{6}$ E.g. in a Fire Incantation (Lambert 1970: 43 1. 33), in SB Lamaštu I 81 (Farber 2014: 79), and in a bilingual hymn to Nergal (K.5268 + = BA 5642 11. 7f, see CAD Š/2 72).

${ }^{7}$ The manuscript was already joined to K.17578 (which duplicates 11. 53-57 with no new text) by W.G. Lambert in 1977.
}

\footnotetext{
${ }^{8}$ The new fragment allows also a better understanding of the end of Theodicy 46, which should be read as [zikar] ‘šap ${ }^{1}-[t i-k a]$, "the word of your lips" (MS 1 [= BM 35405] is to be read, against the copy in Lambert $1960 \mathrm{pl}$. 20, as sikàr šap*-[ti-ka], see the adjoining collation, Fig. 4b).
} 


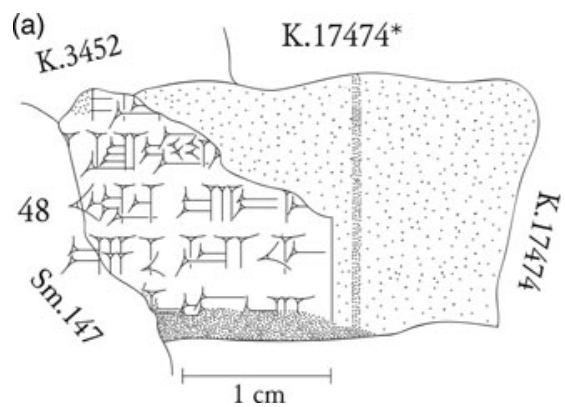

(b) BM 35405

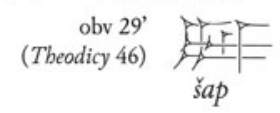

(c) BM 66882+

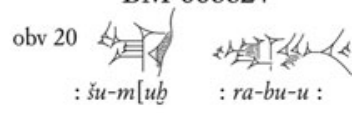

Fig. 4

48. The onager, the wild ass, which nibbles the lushest grass,

49. did he pay attention to the noble plans of a god?

50. The savage lion that devours the choicest meat,

51. did he offer flour to assuage the wrath of a goddess?

48. Only one other attestation of šumuh šamme is booked in the dictionaries, namely its occurrence in the Marduk Prophecy (Borger 1971: 10 Assur IV 12), which represents perhaps an allusion to the Theodicy: rubû šŭ šumuh šammī̌su māta ušakkal, "that prince will feed the land with his lushest grass."

In the ancient commentary BM $66882+$, line 20 was previously thought to refer to Theodicy 49. However, inspection of the tablet reveals that this section of the commentary refers rather to 1. 48, and that it is to be read, against the copy in Lambert 1960 pl. 26 (see the adjoining collation, Fig. 4c), as

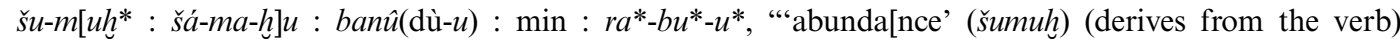
'to grow abunda]ntly' (̌̌amāhu), (which means) 'to grow' (banû); the same (sc. šamāhu) (also means) 'to become big' (rabû)."'9

A different view of the diet of the serrēmu is offered in the Neo-Babylonian letter $A B L 1000$ obv 8'f. (de Vaan 1995: 292-93): zēru ša úsungirti | ša serrēmu ikkalu, "the seed of the sungirtu-plant, which only a wild ass would eat."

49. The beginning of the line is here restored with BM 68589, which at this point reads $a k-k a b$-ti-ia. ${ }^{10}$

5. Once you reach old age, who will be your support? (A fragment of a wisdom text)

Due to the fragmentary state of reconstruction of Mesopotamian literature, Assyriologists are often confronted with what G. Genette called "hypertexts of unknown hypotexts" (Genette 1982: 433). One of them occurs in a line from a famous letter addressed to Ashurbanipal, where Urad-Gula, Chief Scribe of the Assyrian court, lists the difficulties he encounters in his daily life. This "forlorn scholar" (Parpola 1987) has no change of clothes, cannot afford a pair of sandals, owes six minas of silver and, to make matters worse, is no longer a youngster:

[ù ana šanātī(m]u-an-na $\left.{ }^{\text {meš }}\right)$-ia ma-a a-na ši-bu-ti tak-šu-da tu-kul-ta-ka lu-u man-nu

[Moreover, regarding m]y age, it is said: "once you reach old age, who will be your support?" $A B L 1285=S A A 10294$ r 30

In this line Urad-Gula quotes from a poem, as shown, on the one hand, by the metrical structure of the line (ana šĭbūti|takšuda \|tukultaka|lū mannu); on the other, by the fact that it is introduced by the

\footnotetext{
${ }^{9}$ The first equation, $\check{s} a m \bar{a} h u=b a n \hat{u}$, is also attested in a commentary on $A a 9$ (Civil 1979: 269 rev 2), šam-hu : šá$m a h$ : $b a-n u-u$ (on the meaning "to grow, be attractive" of banu in the stative, see Lambert 1998b: 193). The second equation, šamāhu = rabû, albeit obvious, seems to be elsewhere unattested.

${ }^{10}$ The ending -ia is sometimes used for the genitive of nouns ending in a contracted vowel (Lambert 1967b: 130 ad 38 and Geller 2005: 150 ad 28), but here it seems to
}

represent the lengthening of the last vowel caused by interrogative intonation. On the writing DINGIR-DINGIR (var. DINGIR, DINGIR ${ }^{\text {mes }}$ ) for a singular (that it is singular is shown by the parallelism with il-ti-i in 1. 51), see Lambert 1960: 67, id. 1967b: 132 ad 157, George 2003: 804, and Borger 2010: 249. In this case the writing DINGIR-DINGIR could also be explained as a way of rendering the long vowel (ilî) caused by the interrogative intonation of the verse. 


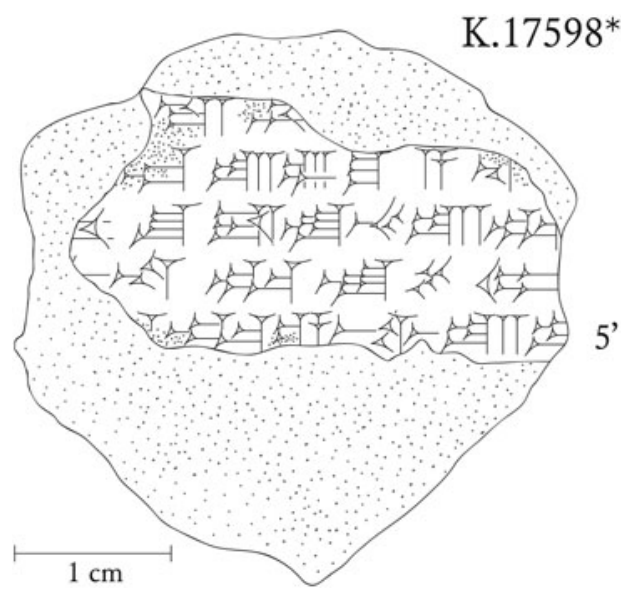

Fig. 5

direct speech particle $(m \bar{a}) .{ }^{11}$ A small fragment from Kuyunjik (K.17598, fig. 5) confirms that this is an allusion and provides a context, albeit scant, for it. Although the work to which it belongs is uncertain, the phraseology is strongly reminiscent of the Theodicy. ${ }^{12}$

1'. [o o o o o o o] $\check{s} a t a[q-b u$-ú (?) o o o o]

2'. [o o o o ta-a]t-ta-lak-ma $a-n[a$ o o o o]

3'. [a-na ši-bu-ti ta]k-šu-da tu-kul-ta-ka [lu-ú man-nu]

4'. [o o o b]u-na-ka tu-še-mi [o o-iš]

5'. [o o o]-x-ka e-dil pe-ta(-)t[a o o- $k a]$

1 '. [...] what you $s[$ aid ...]

2 '. [... you have] walked to [...].

3 '. Once [you hav]e reached [old age, who will be] your support?

4 '. [...] you have reduced your features to [...],

5 , your [...] is closed, but [your ...] is open.

4'. Compare Theodicy 15: namrūti zīmīka ukkuliš tu-še-e-ma, "you have reduced your bright face to a scowl."

\section{The entrails expert ( $B B R$ 1-20 1-28)}

Anyone wishing to become a diviner in ancient Mesopotamia had to fulfil a series of requirements. To have been born in Nippur, Sippar or Babylon, and into a family of diviners, were sine qua non, as was to have bodily features without blemish and, of course, a thorough command of the entire corpus of divination. Such qualifications are the object of several treatises found at Nineveh, a list of which, together with general remarks on the group, can be found in Lambert 1998a.

Lambert divides the treatises into six sections, which contain complementary, if not identical, information. Of these, the first (BBR 1-20 11. 1-115) is the least well preserved: its manuscripts are "very incomplete" and "often break the lines at different points so that its reconstruction is especially difficult" (Lambert 1998a: 142 n. 1).

This situation is partially amended by the discovery of a new fragment, K.14480, which joins K.3272+ (BBR 3) and allows a better understanding of 11. 21-28. In addition, several fragments have been identified in the course of the last fifty years by R. Borger, W.G. Lambert and C.B.F.

\footnotetext{
${ }^{11}$ Several other literary allusions contained within UradGula's letter have been discussed by Parpola 1987: 271-74 and Hurowitz 2008: 78-88.

${ }^{12}$ The fragment could belong to the badly preserved strophe $\mathrm{XVI}$ of the Theodicy, if the first word of 1.3 ' is reconstructed as
}

[áššsi-bu-ti] . Another candidate would be the Counsels of Wisdom, a text much beloved of Mesopotamian correspondents (it is quoted in $A B L 614=S A A 10188 \mathrm{r} 9$ 10, see Parpola 1983: 120; and in a Babylonian letter that mentions Mukīn-zēri, see Lambert 2002). 


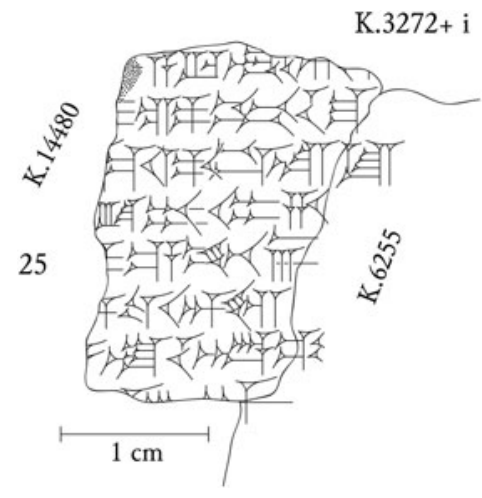

Fig. 6

Walker, and as a result the only edition of the text, that of Zimmern's (1901: 95-105), is now substantially outdated. A re-edition of the whole ritual constitutes a desideratum that would go beyond the scope of this paper, but the identification of the new material calls for a fresh reappraisal of the opening lines. The known manuscripts of this first section are as follows: ${ }^{13}$

A K.3272+ K.6255+ K.7644+ K.8001 (the four of them BBR 3)+ K.13245 (unpubl., Lambert)+ K.14101 $(B B R$ 15, Borger)+ K.14480 (Fig. 6)(+) K.9735 (BBR 13)+ 81-2-4, 256 (BBR 5)(+) K.13270 (unpubl.)

B K.2812 (unpubl.)+ K.3282+ 83-1-18,457 (both $B B R$ 6)(+) K.2834 (BBR 1)

C K.2541 (BBR 4)+ K.10326 (BBR 2)+ K.13286+ K.17613 (both unpubl., Lambert)

D K.3242 (BBR 7)+ K.5357 (unpubl., Walker)+ K.6209 (BBR 12)+ K.6426 (BBR 7)+ K.6502 (BBR 12)+ K.9487 (BBR 7)+ K.9500 (BBR 14)+K.9532 (BBR 12)+K.10786(BBR 71) (+) K.5785 (unpubl., Lambert)+ K.10677 (unpubl., Borger) + K.11934 (BBR 10) (+) K.10917+ K.11949 (both unpubl., Lambert // 19-41)(+) K.21399 (unpubl.)

MSS B, C, and D exhibit sign forms which, while different from one another, are all probably older than the $7^{\text {th }}$ century BC, whereas MS A looks like a typical Ashurbanipal copy. MSS B and C are one-column tablets, but both MS A and D have two columns per side. MS B preserves a colophon on the lower edge stating that it was copied from a wooden writing-board, while MS D has a Nabû-zuqup-kēna colophon according to which it was copied from "older tablets."14

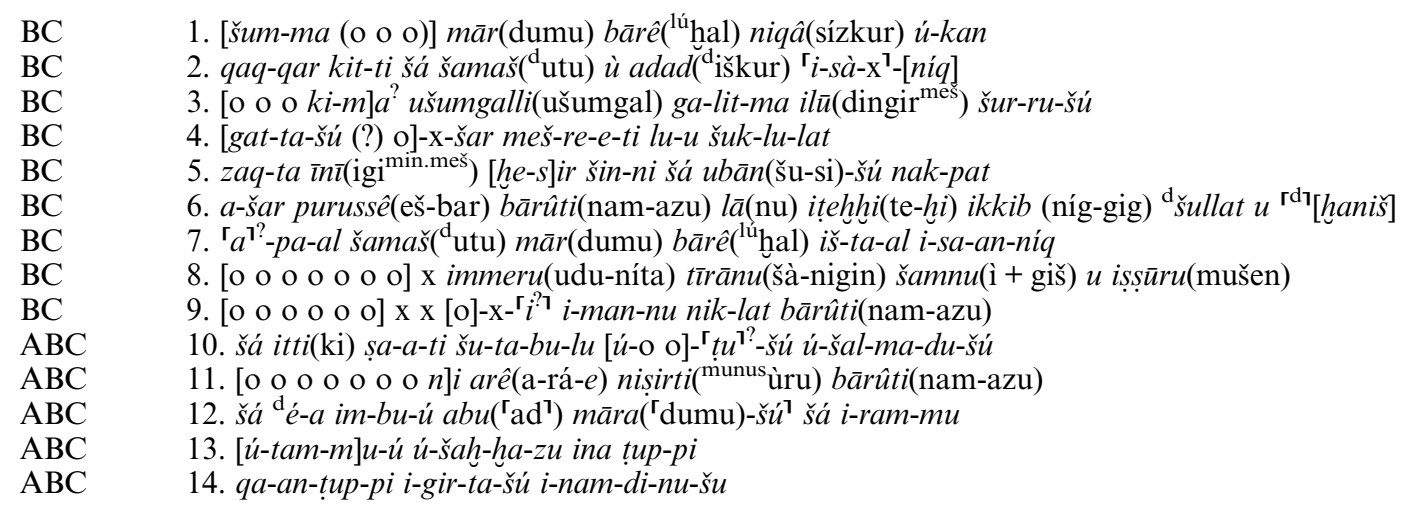

\begin{tabular}{|c|c|c|}
\hline $\mathrm{ABC}$ & 15. [ha-mim (?)] șa-a-ti hi-im-mat šum-mi u mi-šá-ri & (C: AB caret $)$ \\
\hline $\mathrm{A}[\mathrm{B}] \mathrm{C}$ & 16. [a-šar d]i-nim ma-har šamaš( $\left({ }^{\mathrm{d}} \mathrm{utu}\right)$ u adad( ${ }^{\mathrm{d} \text { iškur}) ~ i s a n n i q\left(\operatorname{dim}_{4}\right)-m a}$ & \\
\hline $\mathrm{ABC}$ & 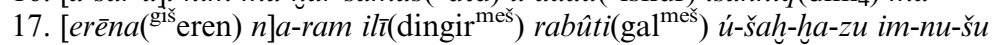 & \\
\hline $\mathrm{ABC}$ & 18. [o o] ta-mit pi-riš-ti bārûti(nam-azu) [(o)]- ${ }^{r} \mathrm{x}^{1}-k a r-r u$ pi-i-šú & \\
\hline $\mathrm{A}[\mathrm{BC}] \mathrm{D}$ & 19. la ka-šid ih-zi-「̌su' [о о о (о)]-pu (x) sa-na-qu & \\
\hline
\end{tabular}

\footnotetext{
${ }^{13}$ This list is based on Walker apud Borger 1975: 328, Lambert 1992: 61b, and id. 1998a: 142.

${ }^{14} \mathrm{As}$ is often the case with prose texts, the various manuscripts divide the lines in different ways, which only
}

occasionally correspond to semantic units. The present edition takes an eclectic approach: the line division of the manuscript that corresponds best to the meaning has been chosen on a line by line basis. 


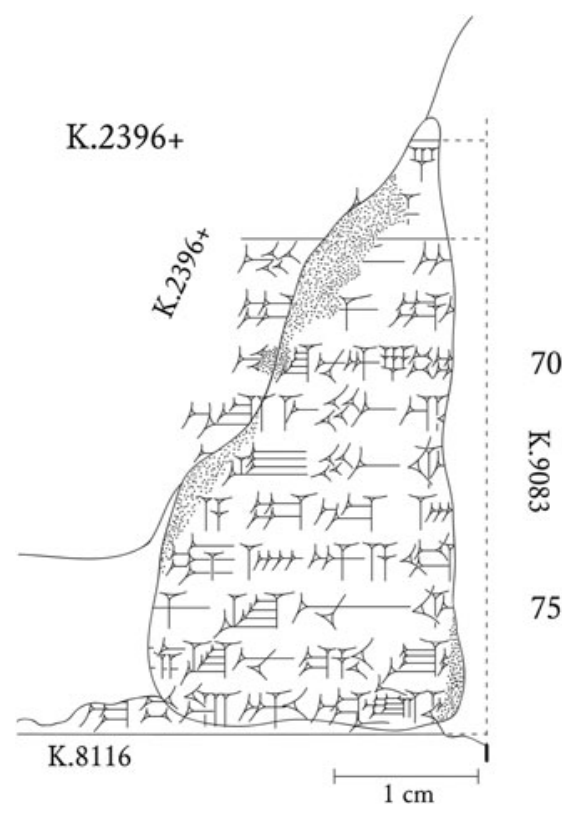

Fig. 7

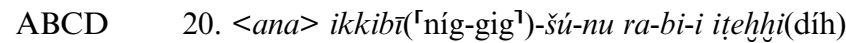

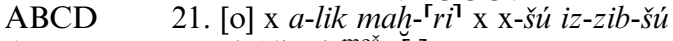

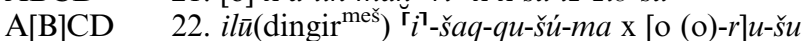

$\mathrm{ABCD} \quad 23$. ina $<a>-\check{a}$ ar di-nim su-lu-ú sur-ra-a-ti

\begin{tabular}{|c|c|c|}
\hline $\mathrm{ACD}$ & 24. [apkal (?)] tākalti(tùn) šum-mi ha-mim tākalti(tùn) têrti $\left({ }^{\mathrm{uzu}} \mathrm{ur}_{5}\right)$ & $(\mathrm{C}: \mathrm{ABD}$ caret $)$ \\
\hline $\mathrm{A}[\mathrm{C}] \mathrm{D}$ & 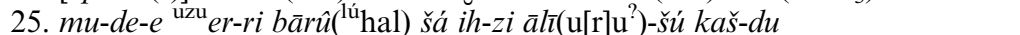 & \\
\hline $\mathrm{AD}$ & 26. [ana mahar(igi)] šamaš( $\left.{ }^{\mathrm{d} 1} \mathrm{utu}\right) u$ adad( ${ }^{\mathrm{d}}$ iškur) tu-kan-nu-šú ta-mit pi-riš-te & \\
\hline $\mathrm{ACD}$ & 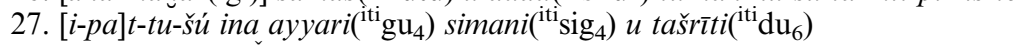 & \\
\hline $\mathrm{ACD}$ & 28. [ina $\left.\operatorname{arh} \bar{\imath}(\mathrm{iti}]^{[\mathrm{rmes}}\right) a n^{7}-n u$-ti ištene ${ }^{\prime \prime} \bar{\imath}($ kin-kin)-ma & \\
\hline
\end{tabular}

$(\mathrm{AD}: \mathrm{C}$ caret $)$

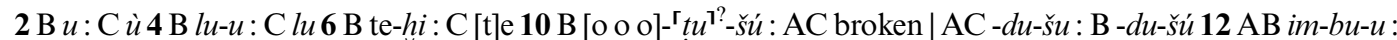
C im-bu-ú $14 \mathrm{~A}$ i-gir-ta-šú i-nam-di-nu-šu : C [i-gir-t] $] a-s ̌ u ~ i-n a m-d i-n u: ~ \mathrm{~B}$ broken $17 \mathrm{C}$ im-nu-šu : A [im-nu-š $] u^{?}:$

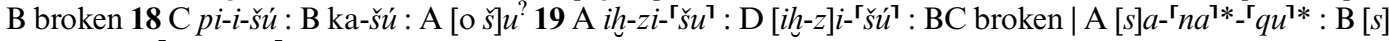
a-na-qu: $\mathrm{C}^{\top} s a-n a-q u{ }^{\top}$ : D broken $20 \mathrm{~A} r a-b i-i: \mathrm{D}$ ra-bi-ia (see above n. 10) : BC broken 21 A $e$-zib-šú : BCD

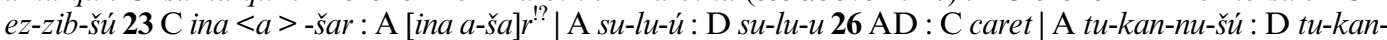

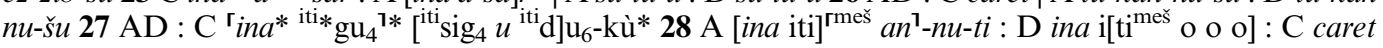

(1) If the diviner is to prepare a sacrifice (2) and to approach the truthful territory of Šamaš and Adad, (3) [a territory] frightful as a great dragon, (where) the gods shall descend to him, (4) [his body ...] must have perfect limbs. (5) The blind, the gap-toothed, or the finger amputee (6) shall not approach the place of the divinatory decision - it is a taboo of Sullat and Haniš.

(7) The diviner shall ponder and check the answer of Šamaš. (8) [Omens pertaining ...] sheep, intestines, oil, and birds (9) [...] he shall enumerate. (9) The subtleties of divination, (10) which he shall interpret with the help of the word lists, they (sc. the gods) shall [...] him and shall make him understand. (11) [...] and the mathematical tablets - secrets of extispicy (12) which Ea called into existence, the father (13) shall teach his favorite son under oath with tablet (14) and stylus, and he shall give them to him as his assignment.

(15) [He who gathers (the knowledge of)] the word lists and the collections of omens and edicts (16) may approach the place of the decision, in the presence of Šamaš and Adad. (17) Cedar - the tree beloved by the great gods - shall take in his right hand, (18) so that they [...] in his mouth the [...], the secret oracle of divination.

(19) He who has not mastered his learning, [...] to check, (20) should he draw near their great sacred (place) (sc. of Šamaš's and Adad's), (21) [...] he who walks ahead, [...] will abandon him, (22) the gods will give him [...] to drink and will [...] him; (23) [in the pl]ace of the oracular decision there will be lies and falsehood. 
(24) [The expert in] the omen-yielding liver, the gatherer (of the knowledge) of the oracle-yielding liver, (25) [the kn] ower of the entrails, the diviner who has mastered the lore of his city; (26) [to the presence of S]amaš and Adad you shall take him, (27) so that [they rev]eal to him (26) the secret oracle. (27) In the months of Ayyāru (II), Simanu (III), and Tašrītu (VII): (28) [during] these [month]s he shall search (for it).

\section{2-3. These lines are duplicated in BBR 75-78 11. 19-20.}

5. On zaqta īn̄, "sharp of eyes," as a euphemism for "blind," see Stol 1986: 295. On [hes]ir šinnī, see Lambert 1998a: 144 and n. 2. On the meaning "to stub" (said of fingers) of nakāpu, see George 2013: 163-64.

9. This line is paralleled in BBR 24+17-18 (Lambert 1998a: 149) (...) pirištiani enlil u ea |śá itti( $\mathrm{ki}$ ) șa-a-ti enūma (ud) $a n u($ an) d en-líl u arâ(a-rá-a) šu-ta-bu-l[u]. The most problematic part of the sentence, ša itti șâti, was interpreted by Lambert 1967a: 133 (and id. 1998a: 144 with n. 4) as "that with commentary," a phrase of uncertain meaning. This understanding was questioned by Koch-Westenholz 2000: 26, who, however, does not propose an alternative.

A different interpretation is offered here. Rather than governing the phrase itti sâti, ša may govern the infinitive verb, šutäbulu. It can then be interpreted as a nominalized command, ${ }^{15}$ "(the secrets) which (the diviner) ought to interpret with (the help) of sâtu-lists." 16 The diviner would thus be advised not to take divinatory texts at face value, but to seek their deeper meaning with the help of șâtu-lists — which are in fact often mentioned as the source of the equations in extispicy commentaries.

"The subtleties of divination" (nik-lat bārûti, Lambert 1998a: 144) parallels pirišti ani enlil u ea in BBR 24+. However, nik-mat bārûti, "the compilation of the divination texts," also seems feasible in the light of the phrase himmāt šummī u mīšarī in 1.15 (q.v.).

11-12. The first word of 1.11 is perhaps [... lišān $] i$ (see n. 16). Compare the second part of the line with nișirti bārûti (...) ša ina GÁN.DIš ea ibnû, "the secret of extispicy, (...) which Ea created in Gandiš" (Koch 2005: 60). 12-14. The same formula can be found in BBR 24+ 20-22 (Lambert 1998a: 149) and in several nisirti bārûti texts (Koch 2005: 543 iii 62f, 546 3'f). The $-u$ endings of the verbs suggest parsing them as subjunctive, but this would result in cumbersome syntax, especially in the case of inaddinū̌su. For want of a better explanation it is assumed here that an attraction to the nearby subjunctive verbs (cf. 1.12 imbu and irammu) has happened. 14. $i$-gir-ta-šú has been translated by Læssøe 1953: 213 as "his commentary," and by Lambert 1998a: 146 as "his certificate," in both cases assuming that it represents an elsewhere unparalleled writing of egirtu, "one column tablet" (for this term, see Radner 1997: 60-62). AHw 897b, however, reads $i$-piš-ta-šu, a term that elsewhere can mean "(tablet inscribed with a) literary work" (Finkel 1999: 332 ad 82).

15. The first word is restored after 1. 24. ${ }^{17}$ himmat šummī $u$ mīšar $\bar{\imath}$ is a baffling expression. šummu could be translated as "clause beginning with 'if'," i.e., "omen" (thus e.g. Oppenheim 1956: 256 n. 2, AHw 1273b, $C A D$ Š/3 280b, and George 2013: 103); but a meaning "law" for mǐšaru makes little sense in this context. ${ }^{18}$ $m \overline{i s}$ aru could conceivably designate an as yet unidentifiable category of extispicy text or, as B.R. Foster suggests (privatim), an "oracular response," since legal terminology is frequently used to express the outcome of extispicy (cf. dīnšu ul iššir below in the commentary to line 23).

18. No restoration suggests itself for the verb before $p \bar{\imath} \check{s} u$; elsewhere the tāmīt pirišti is "revealed" (ipattûšu) or "said" (itammûšu) (CAD T 124b and 1. 26f below).

19. ' $\left.{ }^{\prime}\right]^{1 ?}$-sa-na-qu (sanāqu D?) is unlikely both epigraphically and grammatically, since three different manuscripts (MSS ABC) preserve the same reading (sa-na-qu) with no gemination.

21. Compare BBR 24+ 60-61 (Lambert 1998a: 150): [inadd] ûšu šêdūšu lamassātūušu izzibāšū-ma, "his (sc., the bad diviner's) protective gods shall forsake him, his protective goddesses shall abandon him."

23. On the phrase sullû u surrātu see Jiménez 2013: 243. Here it represents a functional equivalent of dīnšu ul iššir, "his judgment will be wrong," in BBR 24+ 47 (Lambert 1998a: 149).

24. The first word is tentatively restored after the phrase "an expert in oil" (ABGAL İ +GIŠ), said of the diviner in a series of texts (Lambert 1998a: 153). The "liver (täkaltu) ${ }^{19}$ of the omen" is probably to be interpreted as the

${ }^{15}$ On this meaning of phrases with $\check{s} a+$ Infinitive, see Buccellati 1972. On the syntax of $\check{s} a+$ Object + Infinitive, see Aro 1961: 48-57.

${ }^{16}$ On the use of $\breve{s} u t \bar{a} b u l u$ with the meaning "to interpret," said of commentaries, see Frahm 2011: 57. As KochWestenholz 2000: 26 points out, it is unlikely that sâtu here refers to sâtu-commentaries, inasmuch as no such commentaries are known for the Bärûtu series in NeoAssyrian times. However, reference to șâtu lists, paired with lišānu lists, does occur in NA Bārûtu commentaries. In these cases Frahm 2011: 89-90 has proposed to interpret sâtu as "bilingual (lexical) lists," and lišānu as "monolingual lists," and this meaning fits well the present context: the diviner would be urged to interpret divinatory texts with the help of lexical lists - a system that lies behind the genesis of the commentaries. This understanding is supported by the fact that aru-texts, another one of the common sources of explanations in commentaries (cf. e.g. Koch-Westenholz 1999: 156 1l. 49-50 ina arî qabi (...) ina șâti qabi), are also cited in BBR 24+ together with sâtu.

17 A different restoration is proposed by Lambert 1998a: 144 and $n .3$, who considers the beginning of 1.15 to be the end of the preceding clause. Note, however, that MS C preserves a ruling between 14 and 15 , which suggests that 1.15 belongs with what follows, rather than with what precedes.

${ }^{18}$ Landsberger 1939: 220 n. 5, who translated the phrase as "Sammlung von Paragraphen und Rechtssätzen," wondered, "Wozu sollte [...] ein Opferschauer Gesetzeskenntnis benötigen?"

${ }^{19}$ Tákaltu is a word usually identified with the liver: see Glassner 2002 (who understands it as "les viscères dans leur ensemble") and Stol 2006: 107-09, with further bibliography. 
liver in which the gods have written the omen: compare the expression țuppi ilī tākalta pirišti šamê u erșeti, "the tablet of the gods, the liver, a secret of heaven and earth," in BBR 24+ 8, 14, and 16 (Lambert 1998a: 148-49). 25. ' 'URU'-šú follows Lambert 1998a: 145 n. 5, who regards ' ${ }^{\top} \mathrm{SU}^{\top}$ and ${ }^{\top} \mathrm{ZU}^{\top}$ as equally possible.

7. Anu created you to destroy the wicked (BMS 8+BMS 48+)

As part of the ceremony of the Bīt salā' mê, literally "House of sprinkling of water," the king had to spend a night in a cage made of reeds. During this time, he was meant to recite almost thirty incantation-prayers to sundry gods and constellations. At least in the libraries of Ashurbanipal these incantations were collected in several tablets whose subscripts identify them as "sections" (pirsu) of Bīt salä'mê. One of these tablets, dubbed the $8^{\text {th }}$ section and furnished with an Ashurbanipal Typ c-e colophon, contains incantations to Madānu, Ištar, and the Sebetti.

The last incantation, addressed to the Seven Gods, can now be restored thanks to the identification of a new fragment, K.9083 (fig. 7), which joins two further pieces of this tablet, K.2396+ (BMS 8) and K.8116 (BMS 48). The text of the $8^{\text {th }}$ pirsu of Bīt salà' mê has recently been edited and studied by Ambos 2013: 196-200, who kindly made his book available when it was still in proofs.

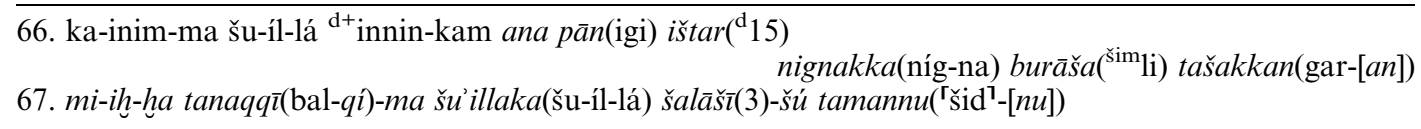

68. én at-tu-nu zappū $\left({ }^{\mathrm{mul}} \mathrm{mul}\right) \check{s} a r-h u-t u_{4} \check{s} a ́ m ~ m u-[\check{s}] i-t[i]$

69. nam-ru-ti šá ilī(dingir $\left.{ }^{\text {meš }}\right)$ rabûti $\left(\right.$ gal $\left.^{\text {meš }}\right)$ zapp $\bar{u}\left({ }^{\mathrm{m}}\left[{ }^{\mathrm{u}}\right]^{1} \mathrm{mu}[1]\right)$

70. a-na hul-lu-qu lem-nu-ti ib-nu-ku-nu-šs ${ }^{\mathrm{d}} a-n u m$ :

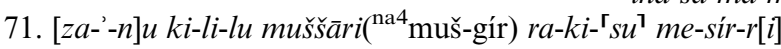

ina šá-ma-me šum( $\left.{ }^{[} \mathrm{mu}{ }^{\mathrm{T}}\right)-k u-n u{ }^{\mathrm{d}}$ imin-bi zapp $\bar{u}\left({ }^{\mathrm{m}}\left[{ }^{\mathrm{ul}} \mathrm{mul}(?)\right]\right)$

72. [o o o] x-su-ti šá til-le-e mu-šam-qí-tum bu-li[m]

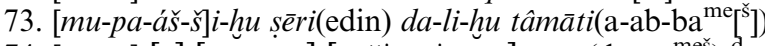

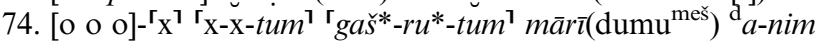

75. [ [ o o o o o o o o $]^{\mathrm{r}} \mathrm{x}^{\mathrm{T}}-k u-n u-s ̌ i$

76. [(о о) a-na da-ra-a-ti dà]- $l i^{1}-l i ́-k u-n u ~ l u d-l u[l]$

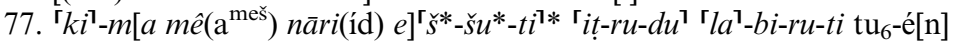

$\frac{\overline{\text { 78. ka-inim-ma šu-íl-lá }}{ }^{\text {mul }} \text { mul-kam }}{\text { (Catchline, rubric and colophon follow) }}$

66. Incantation-Prayer to Ištar. Set juniper in a censer before Ištar,

67 . libate beer and recite the prayer three times.

68. Incantation: You are the splendid Pleiades of the night,

69. the luminous Pleiades of the great gods.

70. Anu created you to destroy the wicked, in heaven your name is "Seven," the "Pleiades".

71. [the ones decora]ted with the serpentine headdress, fastened with the belt,

72. [girded with the] ... of the weaponry that slays wild beasts,

73. [pacif]iers of the desert, roilers of seas,

74. [...] powerful scions of Anu,

75. [...] to you.

76. I shall [forever] sing your praises!

77. As the fresh [water of a river] expelled the old! Incantation.

78. Incantation-Prayer to the Pleiades.

70. If the restoration is correct, the second MUL should have been written over the edge. The appositive use of MUL-MUL and ${ }^{\mathrm{d}}$ INIM-BI is attested also e.g. in Mulapin I i 44 (MUL-MUL ${ }^{\mathrm{d}}{ }_{\text {IMIN-BI DINGIR }}{ }^{\text {meš }}{ }_{\text {GAL }}{ }^{\text {meš }}$, see further Hunger 2003/2005).

72. The first word is perhaps a form of the verb rakāsu, "to tie up, to gird," or a cognate noun, such as maksûtu, "binding."

77. Restored from the end of the prayer Kaksisa 2/3 = Ninurta 4 (Mayer 1990: 471 11. 24-25):

ina šìrīya țurud namtara lemna ša ana nakās napištīya izzazzu

kīma mê nāri eššūti ițrud̄u labīrūti 
Send away from my body the evil Namtaru-demon, who stands by to cut my throat, just as the fresh water from a river expelled the old!

$$
* * *
$$

The incantation shows many phraseological parallels with the epic of Erra and Išum. For instance, the phrase büla šumqutu, "to destroy the animals" (1. 72), is elsewhere attested only in the epic, where it appears in IIc 26 and IV 147; and, as bülšakkan šumqutu, "to destroy the wild animals," in I 43, I 85 and III 15. Also the phrase tâmta dalähu, "to roil the sea" (1. 73) appears there in I 70, IId 27 and IIId 5. The birth of the Sebetti from the sky god Anu (1. 70 and 74) is narrated in Erra and Išum I 28-40. All these parallels suggest that a borrowing took place, either from Erra and Išum to this prayer or vice versa.

\section{Signs from the series Tukumbi Apinduata (The Diviner's Manual)}

The Diviner's Manual is an astrological treatise which instructs the diviner on how to counterbalance an ominous sign with a series of ingenious manipulations, mostly peculiar to this text. ${ }^{20}$ Before the instructional part, however, it contains in its first section (11. 1-37) a catalogue of incipits of the tablets of two series. The first portion (11. 1-24) lists the tablets of the otherwise poorly attested series Tukumbi Apinduata, ${ }^{21}$ which in 11.22 is said to consist of "terrestrial omens" (idāt erșeti). The second portion (11. 25-37) contains the incipits of the tablets of the equally unknown series Kakkabu ša ina pānī̌su șipru, identified in 1.36 as consisting of "celestial omens" (idāt šamê). After both catalogues, the Diviner's Manual famously proclaims the equivalence of terrestrial and celestial signs, and instructs the astrologer on how to annul negative prognoses.

K.7914 joins K.2847, a manuscript of the Diviner's Manual. This join helps to restore almost the whole of the beginning of the text, the only part of it that was missing, and allows a better understanding of the first section of the text, the catalogue of the series Tukumbi Apinduata. The text offered here is the transcription of K.2847+ K.7914, restored with all the other duplicates (for which see below): 22

1. (1) [diš tukum-bi ittu(giskim)] lemettu(hul-tum) ittu(giskim) a-ḩi-tum

2. [o o o o (2) i-ta-a-t]um ha-ța-a-tum lem-né-e-tum

3. [šá libbū(šà) tukum-bi] ${ }^{\mathrm{iti}}$ apin-du $\mathrm{u}_{8}-\mathrm{a}-\mathrm{ta}$

4. (3) [diš tukum-bi gú-gal] 'kù-babbar šám'-šám-da

5. (4) [diš zag-gàr-ra] 'uru' na-nam

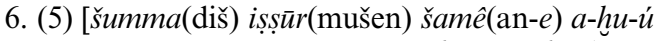

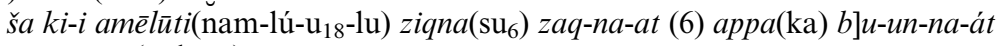

7. [eli(ugu) šêp $\bar{\imath}\left(\right.$ gìr $\left.^{\mathrm{min}}\right)$-šú ziq-pa izzazzu(gub-zu) ip-par-šam-ma

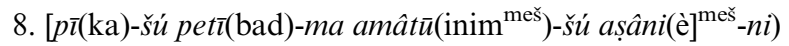

(7) i-na āli(uru) u na-m]e-e-šú innammar(igi)

(1) [If an] unfavorable [sign] or an abnormal sign (2) [...] the ominous and unfavorable signs (3) [which are mentioned in (the tablets) "If] from the month Arahsamna on," (4) ["If the king] buys silver," (5) "[If] there is a city," (6) ["If a strange bird, which is bearded like a human being, whose beak is ex]quisite, (7) [which (normally) stands upright on its legs] is observed fluttering about in the city or its surroundings (8), [it has its mouth opened and words] are coming out from it."

4. This omen is known from $S p T U 185$ o 7'-9' (see Römer 1986: 5455). Other bilingual omens are published in SpTU 1 86, SpTU 145 (see Cavigneaux 1988), SpTU 386 (see Geller 1991/1992: 181-182), and CTN 4 89. ${ }^{23}$ Likewise, several unpublished fragments of bilingual omens from Kuyunjik are mentioned in Borger 1975: 215; Lambert 1978/1979: 111b; and Reiner 1991: 320 n. 124. To these K.13495 should now be added. 5. diš zag-gàr-ra, not translated by Oppenheim (cf. Oppenheim 1974: 203 n. 13), is probably to be taken

\footnotetext{
${ }^{20}$ On the Diviner's Manual, see Oppenheim 1974, KochWestenholz 1995: 137-51, Brown 2000: 120-22, Williams 2002, and Finkel 2014: 70-71.

${ }^{21}$ Besides the Diviner's Manual, the series is mentioned only in a ritual of the kalû to be performed for the reconstruction of a collapsed temple gate (STT 232 obv 3, see Ambos 2004: 29-31 and 196). Note that one of the manuscripts of the Diviner's Manual was owned by a kalû-priest (see below).
}

\footnotetext{
${ }^{22}$ As in the case of text no. 6 , line division varies in the different manuscripts. While the line numbering offered here follows Oppenheim's edition, the numbers in parentheses refer to the line division in K.2847+.

${ }^{23}$ Note that the two BM numbers mentioned in Wiseman \& Black 1995: 18a as further examples of bilingual omens are in fact monolingual Sumerian manuscripts of the Laws of Urnamma, see Civil 2011: 223 MS S $S_{2}$.
} 
together with diš as the conditional conjuction, like diš tukumbi in the previous lines. Note that Nabnītu IVa 366-68 (Finkel 1982: 91) and NBGT III ii 11-13 (Hallock and Landsberger 1956: 160) equate the following words with šumma:

$\begin{array}{ll}\text { Nabnītu IVa 366-68 } & \text { NBGT III ii 11-13 } \\ \text { tukum-bi } & \text { tukum-bi } \\ \text { ud-da } & \text { ud-da } \\ \text { zag-gar-ra } & \text { za-ga-ra }\end{array}$

The last word, $z a(g) g a(r) r a$, is the only one with a variant orthography, so a writing zag-gàr-ra, like in the Diviner's Manual, should not surprise.

uru-na-nam is the name of (a sanctuary in) Nippur (see George 1992: 316 and 446 and Michalowski 2006: 157), but this seems to have no bearing on the present text.

Scholars have often remarked on the puzzling fact that, although the astrological contents of the Diviner's Manual are unique, the great number of manuscripts in which it was preserved suggests that it belonged to the "stream of tradition." ${ }^{24}$ However, over the last forty years the ten manuscripts used by Oppenheim in his edition have been found to belong to three basic manuscripts, one in Babylonian and two in Assyrian script, and to three further tablets which contain additional astrological material. For the reader's convenience, an updated list of manuscripts and new sigla are given here (the letters in parentheses correspond to the sigla in Oppenheim's edition, fragments not used by Oppenheim are in bold):

NinBab1 K.2848 (A)+ Sm.1088+ Sm.1531 (both I, joins by E. Reiner and J.C. Fincke) // 1-41, 49-82

Colophon: GN-šuma-ib[ni], d. of Šumu-libši, lamentation-priest of Enli125

NinAss1 K.2847 (B)+ K.7814 (join by E. Jiménez, copy on Fig. 8a)

// 1-11, 25-48, 49-84

Colophon: Asb Typ b (not copied below)

NinAss2 K.8801+ Rm.2,589 (both C)+ Sm.131 (join by R. Borger, copy on Fig. 8b) ${ }^{26}+$

// $13-45,46-77$

Sm.1077 (G, join by E. Jiménez)

Partial duplicates that incorporate other astrological material are:

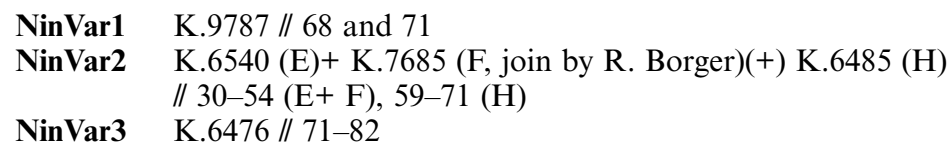

As noted by Oppenheim, a hepi-gloss appears in the same place (1. 67) in MSS NinAss1, NinAss2 and NinVar2, which makes it very likely that these three MSS go back to the same Vorlage. ${ }^{27}$ That all six Ninevite manuscripts had the same Vorlage cannot be proven, however, inasmuch as the line in question is not preserved in NinVar1, NinVar3, and NinBab1. The last of these, NinBab1, is the only exemplar written in Babylonian script, and it was in all likelihood brought to Nineveh from a Babylonian city. The fact that it has a small lacuna at this point leaves the possibility open that this was in fact the Vorlage for all the Assyrian duplicates.

\footnotetext{
${ }^{24}$ Thus e.g. Koch-Westenholz 1995: 137 and Hunger \& Pingree 1999: 23. On the possible date of composition of the Diviner's Manual see also Parpola 1983: 310 n. 565.

${ }^{25}$ The owner's name is written as ${ }^{\text {m.d }}{ }_{\text {KU.SUD.NUN.TU-MU- }}$ $\mathrm{D}\left[\hat{\mathrm{U}}^{2}\right] . \mathrm{d}_{\mathrm{KU}}$.SUD.NUN.TU is equated in god lists with either Amurru or Šakkan (Litke 1998: 127 III 95, 217 VI 230, and 236 1. 106), but both gods are extremely rare in first millennium prosopography. ${ }^{{ }}$KU.SUD.NUN.TU is thus probably a cryptographic writing for a more common deity, perhaps
}

Ea. "Lamentation priest of Enlil" is written playfully as lú $l a-$ gar $\mathrm{d}_{\mathrm{KUR}-\mathrm{GAL}}$, where lúla-gar = kalû $($ Malku IV 15, see Oppenheim 1974: 198 n. 7) and ${ }^{\mathrm{K} U R-G A L}=$ Enlil (Lambert 1957: 11 and 13 1. 41). Gabbay 2014: 125 suggests reading this scholar's name as Ea-šumu-ibni, kalû-priest of Ea, since the god Ea is occasionally identified with Sakkan.

${ }^{26}$ This new fragment contains the following variant readings: $24 t u p-p u$ (1. 22), ' $\grave{u}^{\top}$ (1. 23), ša-mu-ú (1. 25), š[ur-ma] (1. 26).

${ }^{27}$ Oppenheim 1974: 197 n. 1. 
(a)

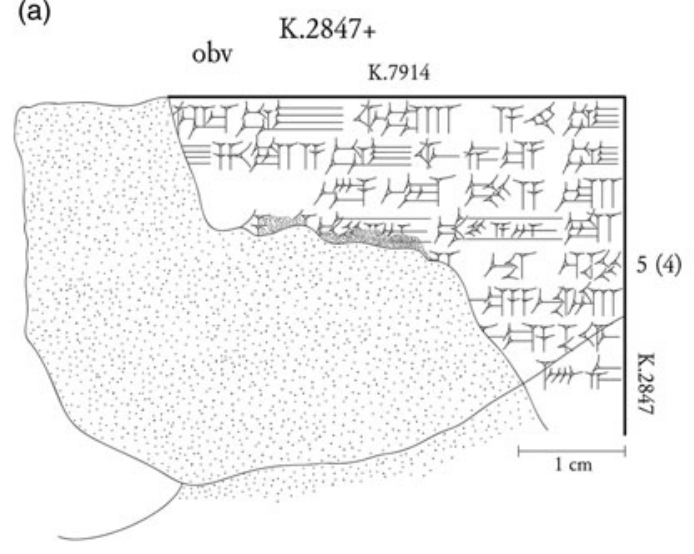

(b)

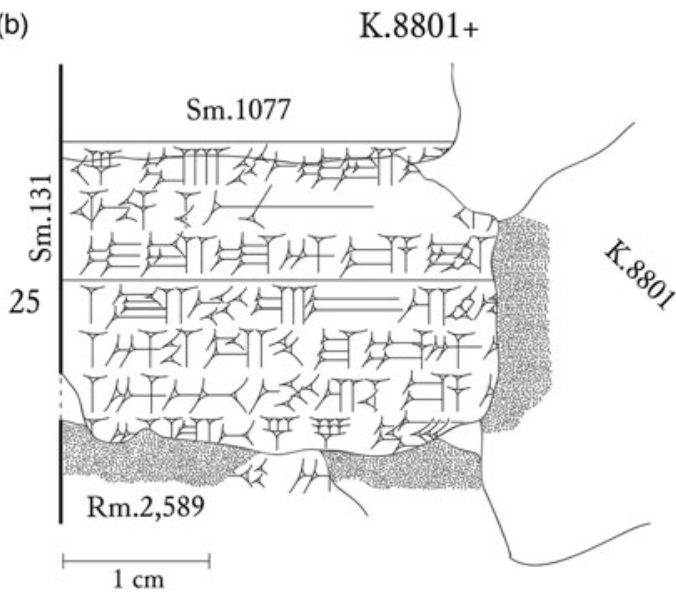

Fig. 8

\section{My bed is the ground! (penitential prayer alsika ilī)}

The prayer alsikka ilı is one of the few extant examples of the group of the šigu-prayers, individual laments addressed to a deity in which the penitent acknowledges his sins and asks the god for absolution. ${ }^{28}$ Until now this prayer was known from two small Nineveh tablets preserving two different recensions: K.2425 (Babyloniaca 3 32) and K.9252 (van der Toorn 1985: pl. 2, with an Asb Typ c-e colophon). It has been edited by Seux 1981: 434-35 and, more recently, by van der Toorn 1985: 137-38.

Two new fragments have been identified: the first one, K.11682 (Fig. 9b), follows the former recension, while the second, Sm.1068 (Fig. 9a), joins the only known manuscript of the latter version, K.9252.

\section{K.9252+ Sm.1068}

1. én $̌$ si-gu-ú al-s[i-ka i] -lí nu-[ha-am]

2. nu-ha-am-ma ì-lí [un-nin]-ni-ia [le-qé]

3. ši-mi ik-ri-bi-i $[a]$ šum-ru-ș[u-ú-ti]

4. maruštu(níg-gig) im-hur-an-n[i] li-mad á[r-hišs]

5. ta-ni-hi-ia ša $\mathrm{Cùu}^{\mathrm{\top}}$ ši-tem-[me]

6. dim-mat ad-mu-mu li- ${ }^{\top} b i l^{\top}-k u s ̌ s\left[\right.$ at mūšs $\left.\left(\mathrm{gi}_{6}\right)(?)\right]$

7. ul-tu ūm(ud-um) be-lí te-nin-[an-ni]

8. ilu(dingir) bān̄̄(dù)-ia tas-bu-su elì(ug[u)-ia]

9. bīta(é) taš-ku-nu ${ }^{\top} a^{\top}-n a k i-l[i-i a]$

10. erš̄ (giš ná-mu) qaq-qa-ru mu-[šáb mūši $\left.\left(\mathrm{gi}_{6}\right)-i\right] a$

11. ek-mé-ku šit-tú '̌̌́um ${ }^{\top}-[r u-s ̦ a-k] u^{?} s\left[a^{?}\right.$-lá-lá]

12. $[\ldots e]-{ }^{\top} \check{S} e^{\top}-[k u](?)$

\section{K.11682 (//K.2425)}

1. [én é-nu-ru $a] l-s i-k[a$ i-lí ši-ma-an-ni]

2. [ši-mi ik-r]i-bi-i[a šum-ru-șu-ú-ti]

3. [ta-ni-hi-i]a šá ma-[gal da-al-pa-ka]

4. [dim-mat] ad-mu-mu [mūšu( $\left.\mathrm{gi}_{6}\right)$ lib-lak-ka]

5. [ul-t]u üm(ud-um) be-[lí te-nin-an-ni]

6. [i-l]i ba-ni-ia [tas-bu-su elì(ugu-ia)]

7. [ek-m]é-ku šit-tú [šum-ru-ṣa-ku șa-lá-lá]

8. [o-m]u šu-ud-lu-pa-[ku o x o o o e-šá-ku]

9. [an]-na áš-ta-d[a-ad na-ša-a ul e-le-'-e]

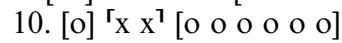

1. Incantation šigû: I have called upon you. My god, relent!

2. Relent, my god! Accept my supplication!

3. Harken to my weary prayers!

4. Learn at once the disgrace that has befallen me!

5. Keep listening to my lament, which I have made!

6. May the night bring you the tears which I weep!

\footnotetext{
${ }^{28}$ On the šig $\hat{u}$-prayers, see Mayer 1976: 15 and 111-13, Seux 1981, van der Toorn 1985, Matini \& Ambos 2009, and Fadhil \& Hilgert 2011.
} 
(a)

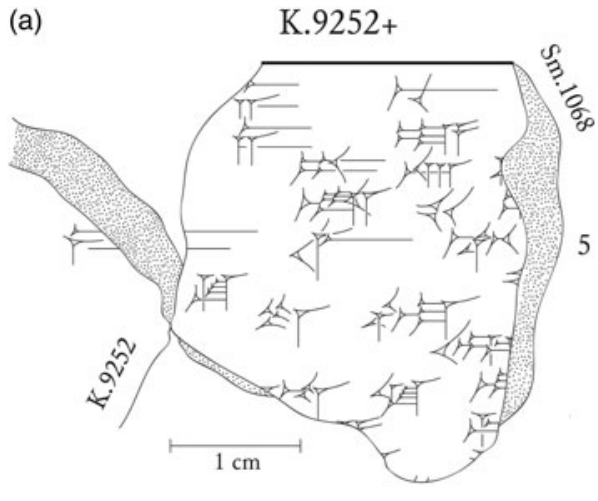

(b) K.11682*

5

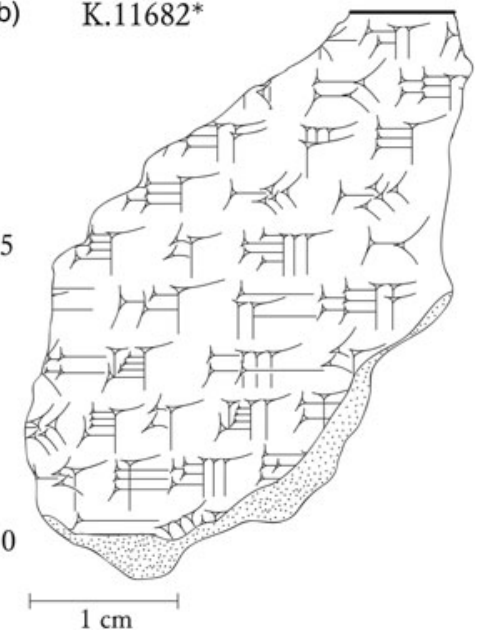

Fig. 9

7. Since the day (you), my lord, punished me,

8. and (you), the god who created me, became furious with me,

9. (since the day) you turned my house into my prison,

10. my bed is the ground, my sleeping place is dust,

11. I am deprived of sleep, distressed by nightmares,

12. I am troubled [in my ...], confused [in my ...].

B 9. I have been enduring a punishment [that I cannot bear.]

A 4. This line finds a parallel in an incantation addressed to Šamaš (Abusch \& Schwemer 2011: 338 1. 22). A 5. The traces at the end of the line in K.9252+ seem to belong to the same long DÜ-sign as the traces at the beginning of Sm.1068. However, no likely reading suggests itself - the reading adopted by van der Toorn 1985: 137, tānēh̄yya ša ēpušu, "my laments which I have made," followed by CAD T 172a, results in awkward syntax.

A 10. Cf. (mihi) cubile terra, "my bed is the ground" (Cicero, Tusculanae disputationes 5, 90). The restoration of $m \bar{u} \breve{s} a b m \bar{u} \breve{s} \bar{l} y a$ in the second half of the verse follows van der Toorn 1985: 137; if correct, the elsewhere unattested phrase mūšab mǚsi, "night abode," would be a synonym of mayyāl mūši, "night bed."

B 9. Cf. K.3515 (OECT 6 13) r 5', which could now be restored as [ar-n]a áš-ta-da-ad našâ ul ile"e.

\section{The god of unfathomable heart (Ashurbanipal's Dedicatory Inscription to Marduk)}

A hymn whose main character is the Assyrian king Ashurbanipal records the dedication of a golden basket (masab hurāși) or, according to one manuscript, of a golden censer (nignak hurăși), to the god Marduk. Of its three parts, the first (11. 1-13) is a hymnic introduction celebrating the god's preeminence. The second (11. 14-25/26), which begins with a self-introduction of the king (1. 14, anāku aššr-bāni-apli), narrates the defeat he inflicted upon Tugdammê, the king of the Cimmerians, and his son. The third section (11. 25/26-50) describes the votive object itself. The historical character of the second part of the text motivated its inclusion in Borger's edition of Ashurbanipal's inscriptions (Borger 1996: 201-03), the most recent edition of the text.

The hymn is known from a long Neo-Babylonian manuscript from Kuyunjik and several smaller Neo-Assyrian fragments. Two new manuscripts have come to light since Borger's edition, both of them from the first part of the inscription, the hymnic introduction. The first of them, K.12582 (OECT 6 5) joins the big Neo-Babylonian manuscript and restores 11. 6-12. The second, Sm.1474, is written in Neo-Assyrian script and might be part of MS C or, less likely, of MS D. The manuscripts known for the text are: 
a K.120B+K.144+ K.3265+ K.3298 (all of them $A B R T 1$ pl. 10-13 and ABRT 2 p. ix)+ K.12582 (OECT $65)$

B $\mathrm{K} .3412$ (IWA pls. 38-39)

C K.11797+ K.13885 (unpubl.) // $1-51$

D $80-7-19,333(\operatorname{Iraq} 30 \mathrm{pl}$. xxv) // 48-51

E Sm.1474 (Fig. 10) // 6-10d

The new manuscripts, and in particular OECT 6 5, suggest a different reconstruction from that adopted by Borger, and the line numeration should be altered accordingly. In the following edition the corresponding numbers from Borger's edition are given in parentheses.

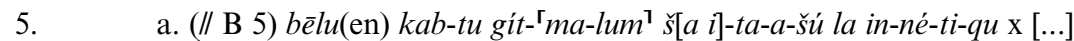

6. $\quad$ a. ď̀à-zu $m u$-de-e libbi(šà) ilī $\left(\mathrm{d}\left[\text { ingir }^{\mathrm{me}}\right]^{\breve{s}}\right) m u$-bal-lu-u nap-har rag-gi šá [...]

E 1' (// B 6). ['šà-zu mu-bal-lu]-u nap-[har ...]

6b. (7) E 2' (// B 7). [pa-qid kul-lat nap-ha]-ri ta-me-e[h ser-re-ti šamê u erseti (?) ...]

6c. (8) E 5' (// B 8). [mu-kil mar-kas 4 šamê(an]- $\left.{ }^{\top} e^{7}\right)$ u erșeti(ki-tim) $m u$-[...]

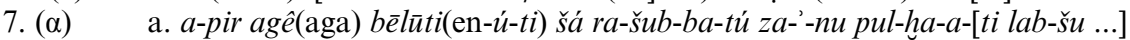
E 3' (// B 9). [o o o bēlūti(en]-ú-ti šá ra-šub-[ba-tú ...]

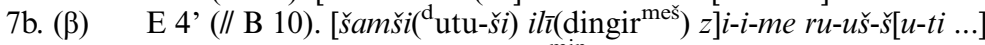

8. $(\gamma) \quad$ a. le-' le-'-ú-ti rap-šá uznī $\left(\mathrm{geštu}^{\mathrm{min}}\right)$ er-šú šal-ba-bu pa[l-ku-ú ...]

E 6' (// B 11). [o o le-'-ú-t] i rap'-šá uznī (geštu $\left.{ }^{\mathrm{min}}\right)$ er-šú [...]

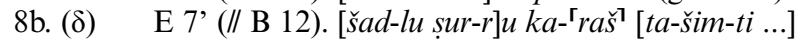

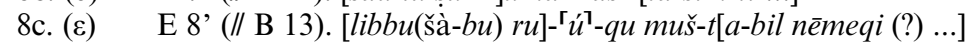

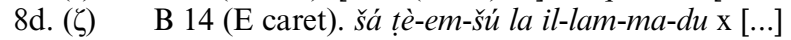

9. $\quad$ a. libbu(šà) ru-ú-qu ma-lik ra-ma-ni-šú ' 'šá ina gi-mir NU TIL ina ta-[...]

E 9' (B caret). [o o o] ma-lik ra-ma-[ni-šú ...]

10. $\quad$ a. be-el kup-pi nag-bi e-de-e u ta-ma-a-ti x [...]

B 15 (E caret). be-el kup-pi nag-bi e-de-e u [...]

10b. (ๆ) B 16 (E caret). ba-nu-ú șal-mat qaqqadi(sag-du) bēel(en) nab-n[i-ti ...]

10c. E 10' (B caret). [o o o] la ú-t $[a-\ldots]$

10d. E 11' (B caret). [o o o] $a b-\mathrm{x}[\ldots]$

11. a (// B 17). bēlu(en) réme-nu-ú le-qu-ú un-nin-ni še-mu-ú [...]

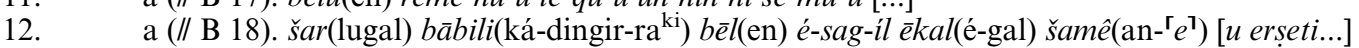

5. Noble, perfect lord, whose boundaries cannot be transgressed, [...],

6. Šazu, who knows the heart of the gods, who destroys all enemies, who [...],

6b. [Guardian of the Univer]se, the holde[ $\mathrm{r}$ of the lead rope of Heaven and Earth ...],

6c. [Sustainer of the bond of Heav]en and Earth, the [...].

7. Who is crowned with the lordly tiara, adorned with terror and clad with fearsome aura [...],

7b. [Sun-god of the gods,] whose features are fiery [...],

8. Most capable of the capable, wise and expert, ingenious and lear[ned ...],

8b. Magnanimous, of all-penetrating mind, [...],

8 c. Of unfathomable heart, who ponders [wisdom ...],

$8 \mathrm{~d}$. Whose intentions cannot be understood [...],

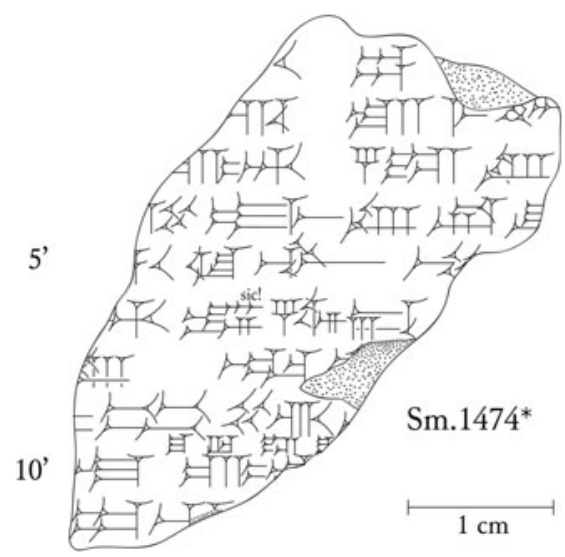

Fig. 10 
9. (The god) of unfathomable heart, the counselor of himself, who in all [...]

10. The lord of springs, floods and seas, [...]

10b. Creator of the black-headed people, the lord of the crea[tion ...],

$10 \mathrm{c}-\mathrm{d} . .$.

11. Merciful lord who accepts prayers and heeds [supplications, ...],

12. King of Babylon, lord of Esagil - the palace of Heaven [and Earth ...]

5. Cf. mamman ina il̄̄ itukka lā ittiq "no one among the gods can transgress his boundaries" (Enūma Eliš IV 10).

6. The etymological explanation of the name Šazu as $m \bar{u} d \hat{e}$ libbi ili appears in MS a but is absent from all the Assyrian manuscripts. Elsewhere it occurs, among other texts, in Enūma Eliš VII 35 (see Hurowitz 2010: 91 and Lambert 2013: 484-85).

7. The restoration [labšu] follows $C A D \mathrm{Z} 48 \mathrm{a}$.

7b. On this line, see George 1992: 139 n. 37 and Hurowitz 2010: 90.

8c. muštābil nēmeqi is restored after a prayer to Marduk edited by Mayer 1990: 4561.3.

$8 \mathrm{c}-9$. The fact that both lines $8 \mathrm{c}$ and 9 begin with libbu rūqu prompted a homoeoteleuton in MSS B and E. While the scribe of MS E omitted 1. $8 \mathrm{~d}$ and 9, and only later did he try to amend his error by copying 1.9 in small script beneath $8 \mathrm{c}$ (see copy); that of MS B omitted 1.9 altogether.

libbu rūqu, "distant (i.e., unfathomable) heart" is a common epithet of Marduk (CAD R 425a). According to Lambert 1990: 215b and 2013: 484 485, it is a literal translation from the Sumerian šà sù, whence its occasional use as a playful translation of the divine name Šazu.

10c-d. The text in MS E seems not to be duplicated by either MS a or MS B.

The Babylonian (MS a) and the Assyrian versions (all other MSS) of this text exhibit profound divergences. However, the tablets written in Assyrian script, which preserve longer versions of the poem, also disagree with one another in detail. As already mentioned, one of the Assyrian manuscripts (MS B) states that the hymn was accompanied by the offering of a "golden censer" (nignak hurạsis), while the Babylonian manuscript, and one of the Assyrian ones (MS D), speaks of a "golden basket" (masab hurassi). Moreover, the subscript of the Babylonian tablet states that the tablet has a total of 50 lines, while one of the Assyrian fragments, MS D preserves the number 55. The other Assyrian manuscripts might have been even longer, since the portion of the text that they preserve contains no fewer than nine lines absent from the Babylonian version.

It is obvious from this that there existed not only two versions of this hymn - one Babylonian and one Assyrian -, but rather a spectrum of them, adapted on different occasions to accompany different offerings. It is conceivable that these different versions also recorded different historical events, not only the Elamite defeat by Ashurbanipal, but this is as yet difficult to ascertain, since the historical section of the inscription (11. 14-25/26) is so far attested only in the Babylonian manuscript.

\section{The caring hands of the god (Mǔšsu'u VII)}

The seventh tablet of the exorcistic series Muššu opens with a long and elaborate bilingual incantation that aims at exorcizing whatever disease is affecting the patient. It is divided into three parts: the first one (11. 1-19) is a long list of god names, some of them only poorly attested elsewhere. This is seamlessly followed by a list of diseases (11. 20-26), which is combined with the list of gods in the final part of the incantation (11. 27-32), where the gods from the former list are invoked to expel the diseases mentioned in the latter. ${ }^{29}$

This incantation is preserved in tablets from Babylon, Uruk, Sippar, and Kuyunjik. Two Ninevite manuscripts of it are known: the small fragment Sm.1668+ Sm.2181 (MS C+ E, now rejoined), and K.4918+ (MS D). The latter is a very broken tablet: when first copied by B. Böck (2007: pls.

\footnotetext{
${ }^{29}$ In some manuscripts of Muššu $u$ VII, this incantation is followed by another one, Udughul edina re'a, borrowed from the series Udughul (Udughul VII 98-127= edited by Geller 2007: 139-41). In others, among them the one dealt with
}

here, Mǔšsu'u VII consists of only this incantation, and Udughul edina re'a represents the beginning of a different tablet. On this question see further Finkel 1991: 98-99, Böck 2007: 65-66, and ead. 2009: 133. 
xxxiv-xxxv), it consisted of 12 fragments; now three more fragments have been identified, so this small tablet currently consists of 15 rejoined pieces. ${ }^{30}$

The text has been recently edited in Böck 2007: 241-60, with updates in Böck 2009: 133-37 and Lambert 2013: 157-58. A recent translation can be found in Böck 2010: 149-50.

10. ['b]ur-nun-sa ${ }_{5}$ lú [hul-gál s]ág-' ${ }^{\mathrm{T}} \mathrm{ke}_{4}{ }^{\top}$

$\mathrm{d}$ min $s a-k[i p \varnothing l] e m-[n] i$

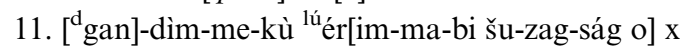

[d] $]^{\mathrm{T}} \min ^{\mathrm{T}} m u-$-ra-['i-bat $a-a-b i$ o o o]

12. ['gada-lá-ab]zu ka-ba-a-ni u[šs̆ 11 -zu o o o o]

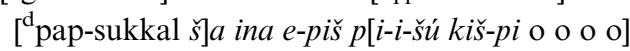

13. ['ensí-gál]-abzu níĝ-[zi níĝ-si-sá ki àĝ-gáa (?)]

traces

19. đnin-gìrim nin a-gúb-ba dadda[g-ga]

${ }^{\mathrm{d}} \min$ be-let a-gub-bé-e e[l-li]

20. saĝ-gig zú-gig sa-gig s[u-gig] mu-ru-us qaq-qa-di min šin-ni ki-is-sa-tú e[k-ke-tú]

21. aš-gar mu- ${ }^{-{ }^{\prime}}{ }^{1 *}$-a te-a [zé-zé (?)]

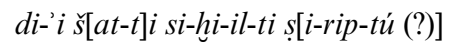

22. a-za-ad mu- ${ }^{\top}$ ú-a $^{\top} \mathrm{r}_{\mathrm{a}} \mathrm{šd}_{7}{ }^{\top}$-da [diri-ga] šu-ru-up-p[a-a šat-t]i šá hur-ba-šá $m[a-l u-u]$

23. ud-da-tab-ba i[m-ri-a] šu-tag-ga na[m-tar-ra] hi-mit șe-[e-ti ši-bit šá]-a-ri li-pit na[m-ta-ri]

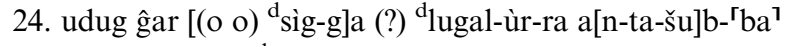

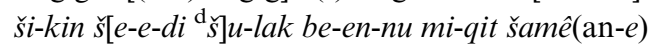

25. udug gedi[m gi]g-ga a-na-me-a-bi ú-tuk-ku ' $e^{\top}-t[e m-m u]$ mur-șu ma-la ba-šu-u

26. zú-muš-ì-gu ${ }_{7}$-e s[u l]ú-u ${ }_{19}-{ }^{-l u}-{ }^{\top} \mathrm{ke}_{4}{ }^{\top}$ ì-ĝál-la pa-šit-tum ša ina zu-mur ${ }^{\top} a^{\top}-m e-l i b a-\breve{s a ́}-t_{4}$

27. su-bu ${ }_{5}$-ra hul-ĝál-la-' ${ }^{\top} b^{-}$-ta ${ }^{\top}$ zi-ge-eš ina tir-rat le-mut-ti [l]i-is-su-hu-ka

$* * *$

30. [ninda a-me]š ka-zu [hé-ni-í]b-dùg-ga-e-ne [a]-ka-lu ù mu- ${ }^{\top}$ ú$^{\prime}$ [ina pi-i-k]a li-tib-bu

31. ki nam-ti-la-ke ${ }_{4}$ gìri-[zu gu]b-' ${ }^{-} \mathrm{bu}-\mathrm{dè}{ }^{\top}$ i-na qaq-qar ba-la-t[i še-ep-ka li-iz-zi-zu]

32. šu sig ${ }_{5}$-ga diĝir-ra-na-šè nam-ti-la si[lim-ma-(mu) hé]-'rni-íb-túm-mu'-n[e]

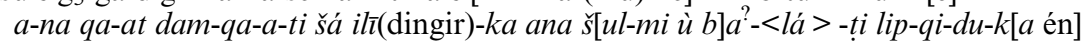

Catchline and rubric. én udug-hul an-edin-na r[ $\left[\mathrm{e}_{6}\right.$-a dub 7-k]am muššsu- $[u]$

Colophon. Asb Typ q (Hunger 1968: 103 no. 329)

10. Burnunsa, he who overthrows the enemy,

11. Gandimmeku, she who makes the foe [...] tremble,

12. Gadalabzu / Papsukkal, at whose command witchcraft [is destroyed],

13. Ensigalabzu, he who loves truth and justice, (...)

19. (and) Ningirim, the lady of the holy water vessel.

20. Head disease, tooth disease, muscle disease and b[ody disease] (Akk. skin disease and itching), 
(a)

obv

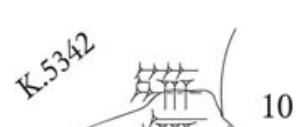

F⿻二丨 10

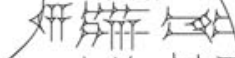

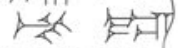
स्तH HATF क्ष

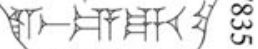

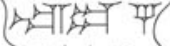

31

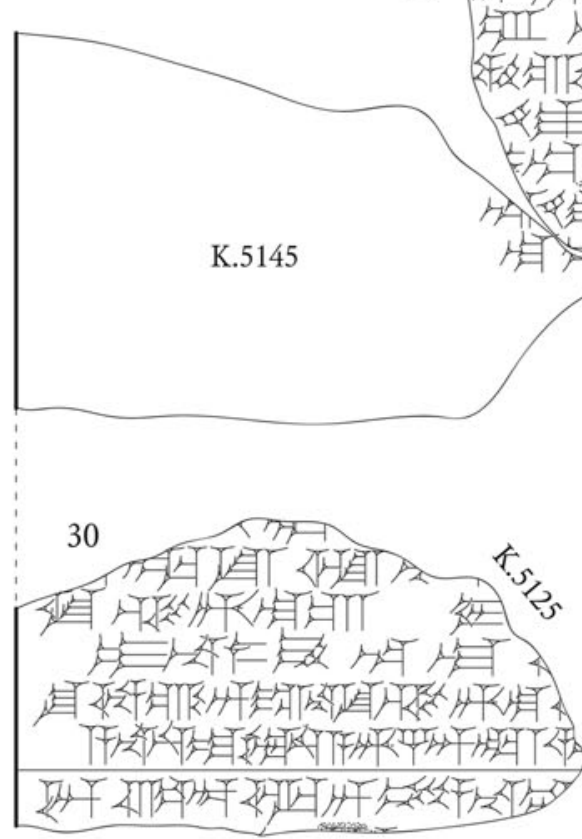

(b) BM 53631*
K.4918+

rev

K.13519

K.5029

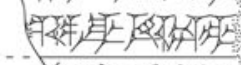

K.5275

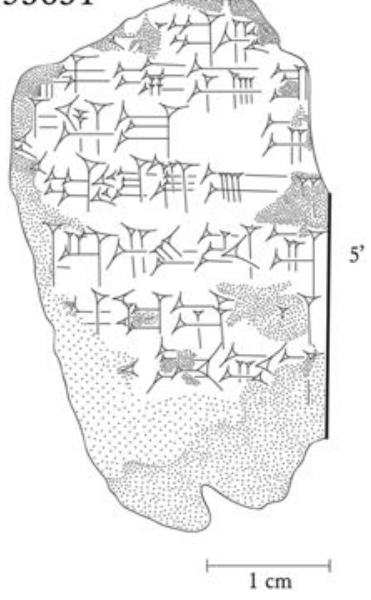

Fig. 11 
21. Seasonal headache, puncture wound, di[scoloration],

22. Seasonal cold, [full of cold water] (Akk. which is full of shivers),

23. Heat stroke, wind burn, deathly plague,

24. "Appearance of the $\breve{s} \bar{e} d u$-spirit," Sulak, "lord of the roof" (Akk. epilepsy), and "falling sickness,"

25. demons, ghosts and diseases, as many as there are,

26. "obliterator," who is in a person's body,

27. May they (sc., the gods mentioned in 11. 1-19) expel them

(the above mentioned diseases) with the lash of evil!

(...)

30. May they make food and drink agreeable to your taste!

31. Your foot shall stand on a land of life! (Akk. May your feet stand on a land of life!)

32. May they entrust you, sound and safe, to the caring hands of your god! [Incantation].

Catchline and rubric. "Incantation: The evil demon who walks in the steppe."

[Seven]th tablet of Muššu u.

11. In $A n=A n u$ Gandimmeku is a daughter of Ea or Namtar (Lambert 1972/1975). The reading of her name here follows Selz apud Jursa 2001/2002: 85a.

20. For the sequence of diseases su-gú sa-gú \| kissatu ekketu cf. the medical commentaries $S p T U 151$ r 5 and 52 6-7. Compare also Muššu $u$ VI 12: su-gu -e sa-gu $_{7}$-e \| kissatu ekketu, after which the end of this line is tentatively restored.

21. mu-ú-a is assumed to represent mu, "year," with a genitive ending. On the orthography, cf. mu-ú-a, "in (this) year," in MSL 12511.511 and in the proverb SP 5 A 72 (see Gordon 1958: 53b and Alster 1997: I 133 and II 405, note that a similar bilingual proverb from Kuyunjik cited ibid. reads mu-àm). BM 46297+ (MS A) reads perhaps mu-ü!ú-a at this point.

The restoration at the end is tentative. The equation zé-zé $=$ șiriptu would be otherwise unattested, but compare zé-zé = șurrupu in Nabnītu XXIII 156 (Finkel 1982: 216).

22. BM 46297+ (MS A) reads šu-ru-up-pe-e šat*-t[um ...]. On "seasonal" dỉu and šuruppî diseases, see Stol 2007: 15-16 and Lambert 2007: 36-37 11. 245-46.

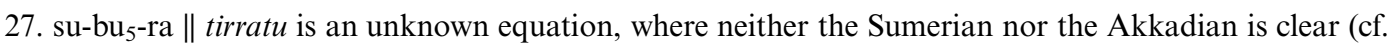
Scurlock 2011: 101).

31. On the interpretation of this line see Schramm 2008: 225 ad 37/38.

32. Compare the similar line in ك̌urpu V-VI $170 \mathrm{f}$.: šu sa ${ }_{6}$-ga dingir-r[a-na-šè hé]-en-ši-in-gi ${ }_{4}$-gi ${ }_{4} \| a$-na qa-at dam-[qa-a-t]i šá ilī(dingir)-šú lip-pa-qid, and in Saggig (CT 1722 ii 145 f., SpTU 365 r 15 f. = Muššu'u II 50, and SpTU 22104 f.). Sm.1668+Sm.2181 (MS C+ E) reads [... b]a-lá-ti l[ip*-qi-du-ka ...].

A new manuscript of this incantation was identified while studying literary fragments from the British Museum's "Sippar Collection," after the above was submitted. BM 53631 (82-3-23,4669, here Fig. 11b) preserves the line ends of Mǔšu'u VII 7-10. It could be part of the same manuscript as BM 69903 (AH.82-9-18,9903), a small fragment from Sippar published by Böck 2009: 135, but the script of the new fragment is considerably less slanted.

The new fragment adds little to the known text, but it contains some remarkable spellings, such as

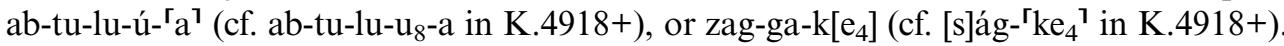

1 '. (7) [ ['tu-tu šìr-kù-ga-bi uš ${ }_{11}$-r]i-a ab-zi-[ir-zi-ir]

2'. (7) [marduk ša ina šerkugêšu ruhêe] ' $\dot{u}^{\top}$-pa-as-sa-su

3'. (8) ['̌̌̀̀-zu diĝir suh é]rim-ma-ke 4 [marduk ilu muballû $a-a-b] i$

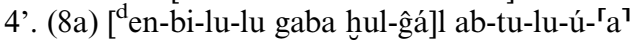
[marduk mune"e irti lemni]

5' (9). [ ${ }^{d}$ namma šu ${ }^{d}$ nam-tar-r]a? gá-ge-da-ke 4 $\left[{ }^{\mathrm{d}} \mathrm{MIN} \check{s}\right.$ a ina qāt namtari igammelu]

6'. (9a) [ ${ }^{\mathrm{d}}$ nanše šu tag-ga-bi urì-e (?) a]k?-ke-e-[k] $\mathrm{e}_{4}$ [ ${ }^{\mathrm{d}} \mathrm{MIN}$ ša lipit qāaț̌̌su nāṣiru]

7’. (10) [ ${ }^{\mathrm{d}}$ bur-nun-sa ${ }_{5}$ lú hul-ĝá]l zag-ga-k[e $\left.\mathrm{e}_{4}\right]$ [ ${ }^{\mathrm{d}} \mathrm{MIN}$ sākip lemni] 
As is often the case, the first edition of a text facilitates the identification of additional manuscripts. In the case of the series Mušš $u$, several small pieces have been identified by the author, which are cursorily listed here for the convenience of a future editor: BM 37243 (Mušš ${ }^{\prime} u$ I 49-55 and II 1), K.13821 (Muššiu IV 67-73), BM 38066 (Muššu'u V 112-119), K.16347 (Muššu'u V 123-128), UM 55-21-29 (obv b = Muššu $u$ VIII 44-50).

\section{Bibliography}

Abusch, T., and Schwemer, D.

- 2011. Corpus of Mesopotamian Anti-Witchcraft Rituals. Volume One. AMD no. 8/1. Leiden, Boston: Brill. Al-Rawi, F.N.H., and George, A. R.

2014. Back to the Cedar Forest: The Beginning and End of Tablet V of the Standard Babylonian Epic of Gilgameš. JCS 66: 69-90.

Alster, B.

— 1997, Proverbs of Ancient Sumer: The World's Earliest Proverb Collections. Bethesda, Maryland: CDL Press.

Ambos, C.

- 2004. Mesopotamische Baurituale aus dem 1. Jahrtausend v. Chr. Dresden: Islet.

2013. Der König im Gefängnis und das Neujahrsfest im Herbst. Mechanismen der Legitimation des babylonischen Herrschers im 1. Jahrtausend v. Chr. und ihre Geschichte. Dresden: Islet.

Aro, J.

1961. Die akkadischen Infinitivkonstruktionen. StOr no. 26. Helsinki: Societas Orientalis Fennica.

Böck, B.

- 2007. Das Handbuch Muššu'u "Einreibung”. Eine Serie sumerischer und akkadischer Beschwörungen aus dem 1. Jt. vor Chr. BPOA no. 7. Madrid: CSIC.

— 2009. Three New Sources of Muššiu. JCS 61: 133-38.

— 2010. 2.16 Muššu'u-Beschwörungen. In: Texte aus der Umwelt des Alten Testaments. Band 5. Texte zur Heilkunde, ed. B. Janowski and D. Schwemer. TUAT NF no. 5. Pp. 147-52. Gütersloh: Gütersloher Verlagshaus.

Borger, R.

1971. Gott Marduk und Gott-König Šulgi als Propheten. Zwei prophetische Texte. BiOr 28: 3-24.

— 1975. Handbuch der Keilschriftliteratur. Band II. Supplement zu Band I. Berlin, New York: de Gruyter.

— 1996. Beiträge zum Inschriftenwerk Assurbanipals. Die Prismenklassen A, B, C =K, D, E, F, G, H, J und T sowie andere Inschriften. Wiesbaden: Harrassowitz.

- 2010. Mesopotamisches Zeichenlexikon. Zweite, revidierte und aktualisierte Auflage. AOAT no. 305. Münster: Ugarit-Verlag.

Brown, D.

2000. Mesopotamian Planetary Astronomy-Astrology. CM no. 18. Groningen: Styx.

Buccellati, G.

1972. On the Use of Akkadian Infinitive After "ša" or Construct State. JSS 17: 1-29.

Cavigneaux, A.

Civil, M.

1988. Un texte médical bilingue. $N A B U 1988 / 24$.

1979. Ea $A=n \hat{a} q u, A a A=n a ̂ q u$, with their Forerunners and Related Texts. MSL no. 14. Rome: Pontificium Institutum Biblicum.

2011. The Law Collection of Ur-Namma. In: Cuneiform Royal Inscriptions and Related Texts in the Schoyen Collection, ed. A. R. George. CUSAS no. 17. Pp. 221-86. Bethesda, Maryland: CDL Press.

de Vaan, J. M. C. T.

1995. »Ich bin eine Schwertklinge des Königs«. Die Sprache des Bēl-ibni. AOAT no. 242. Kevelaer, Neukirchen-Vluyn: Butzon \& Bercker, Neukirchener Verlag.

Fadhil, A., and Hilgert, M.

— 2011. "Verwandelt meine Verfehlungen in Gutes!" Ein šigu-Gebet an Marduk aus dem Bestand der «Sippar-Bibliothek». In: Akkade is King. A collection of papers by friends and colleagues presented to Aage Westenholz on the occasion of his 70th birthday, ed. G. Barjamovic, J. L. Dahl, U. S. Koch, W. Sommerfeld and J. Goodnick-Westenholz. PIHANS no. 118. Pp. 93-109. Leiden: Nederlands Instituut voor het Nabije Oosten.

Farber, W.

2014. Lamaštu. An Edition of the Canonical Series of Lamaštu Incantations and Rituals and Related Texts from the Second and First Millennia B.C. MC no. 17. Winona Lake: Eisenbrauns. 
Finkel, I. L.

1982. The Series $S I G_{7} . A L A N=$ Nabnītu. MSL no. 16. Rome: Pontificium Institutum Biblicum. 1991. Muššu'u, Qutāru and the scribe Tanittu-Bēl. In: Velles Paraules. Ancient Near Eastern Studies in Honor of Miguel Civil on the Occasion of his Sixty-Fifth Birthday, ed. P. Michalowski, P. Steinkeller, E. C. Stone and R. L. Zettler. Aula Orientalis no. 9. Pp. 91-104. Sabadell: Ausa.

— 1999. The Lament of Nabû-šuma-ukîn. In: 2000 v. Chr. Politische, wirtschaftliche und kulturelle Entwicklung im Zeichen einer Jahrtausendwende, ed. J.-W. Meyer and W. Sommerfeld. CDOG no. 3. Pp. 323-42. Saarbrücken: Saarbrücker Druckerei und Verlag.

2014. The Ark Before Noah. Decoding the Story of the Flood. London: Hodder \& Stoughton.

Frahm, E.

2011. Babylonian and Assyrian Text Commentaries. Origins of Interpretation. GMTR no. 5. Münster: Ugarit-Verlag.

Gabbay, U.

2014. The kalû Priest and kalûtu Literature in Assyria. Orient. 49: 115-144.

Geller, M. J.

— 1991/1992. Review of von Weiher SpTU 3. AfO 38/39: 179-82.

2005. Documents of the Incantation Priest: Utukkū lemnūtu. In: Cuneiform Texts in the Metropolitan Museum of Art. Volume II: Literary and Scholastic Texts of the First Millennium BC, ed. I. Spar and W. G. Lambert. Pp. 134-54. New York: Brepols.

2007. Evil Demons: The canonical Utukkū Lemnūtu incantations. Introduction, Cuneiform Text, and Transliteration with a Translation and Glossary. SAACT no. 5. Helsinki: The Neo-Assyrian Text Corpus Project.

Genette, G.

— 1982. Palimpsestes. La littérature au second degré. Paris: Éditions du Seuil.

George, A. R.

1992. Babylonian Topographical Texts. OLA no. 40. Leuven: Peeters.

2003. The Babylonian Gilgamesh Epic. Introduction, Critical Edition and Cuneiform Texts. Oxford: Oxford University Press.

2013. Babylonian Divinatory Texts Chiefly in the Schøyen Collection, with an appendix of material from the papers of $W$. G. Lambert. CUSAS no. 18. Bethesda, Maryland: CDL Press.

Glassner, J.-J. 2002. takāltu. NABU 2002/8.

Gordon, E. I. 1958. Sumerian Animal Proverbs and Fables: "Collection Five" (Conclusion). JCS 12: 43-75.

Hallock, R., and Landsberger, B.

1956. Neo-Babylonian Grammatical Texts. In: Materialien zum sumerischen Lexikon IV, ed. B. Landsberger, R. Hallock, T. Jacobsen and A. Falkenstein. Pp. 129-202. Roma: Pontificium Institutum Biblicum.

Hunger, $\mathrm{H}$.

— 1968. Babylonische und assyrische Kolophone. AOAT no. 2. Neukirchen-Vluyn: Neukirchener Verlag. 2003/2005. Plejaden. Reallexikon der Assyriologie 10: 592.

and Pingree, D.

1999. Astral Sciences in Mesopotamia. HdO no. 44. Leiden, Boston: Brill.

Hurowitz, V. A.

2008. Tales of Two Sages - Towards an Image of the "Wise Man" in Akkadian Writings. In: Scribes, Sages, and Seers. The Sage in the Eastern Mediterranean World, ed. L. G. Perdue. Pp. 64-94. Göttingen: Vandenhoeck \& Ruprecht.

2010. Name Midrashim and Word Plays on Names in Akkadian Historical Writings. In: A Woman of Valor: Jerusalem Ancient Near Eastern Studies in Honor of Joan Goodnick Westenholz, ed. W. Horowitz, U. Gabbay and F. Vukosavović. BPOA no. 8. Pp. 87-104. Madrid: CSIC.

Jiménez, E.

2013. "The Creation of the King": A Reappraisal. Kaskal 10: 235-54.

Jursa, M.

2001/2002. Göttliche Gärtner? Eine bemerkenswerte Liste. AfO 48/49: 76-89.

Koch-[Westenholz], U. S.

1995. Mesopotamian Astrology. An Introduction to Babylonian and Assyrian Celestial Divination. CNIP no. 19. Copenhagen: Museum Tusculanum.

1999. The Astrological Commentary Šumma Sîn ina tāmartīšu Tablet 1. ResOr 12: 149-165.

2000. Babylonian Liver Omens. The Chapters Manzāzu, Padānu and Pān Tākalti of the Babylonian Extispicy Series mainly from Aššurbanipal's Library. CNIP no. 25. Copenhagen: Museum Tusculanum. 
2005. Secrets of Extispicy. The Chapter Multābiltu of the Babylonian Extispicy Series and Nișirti bārûti Texts mainly from Aššrbanipal's Library. AOAT no. 326. Münster: Ugarit-Verlag.

Læssøe, J.

- 1953. Literacy and Oral Tradition in Ancient Mesopotamia. In: Studia Orientalia Ioanni Pedersen Septuagenario a Collegis Discipulis Amicis Dicata, ed. F. Hvidberg. Pp. 205-218. Copenhagen: Munksgaard.

Lambert, W. G.

1957. Ancestors, Authors, and Canonicity. JCS 11: 1-14.

1960. Babylonian Wisdom Literature. Oxford: Clarendon Press.

1967a. Enmeduranki and Related Matters. JCS 21: 126-38.

1967b. The Gula Hymn of Bullutsa-rabi. OrNS 36: 105-32.

1970. Fire Incantations. AfO 23: 39-45.

—1972/1975. Hedimmeku. Reallexikon der Assyriologie 4: 244a.

1978/1979. Review of Hunger SpTU 1. AfO 26: 110-11.

1990. Etymology, Ancient Near Eastern. In: A Dictionary of Biblical Interpretation, ed. R. J. Coggins and J. L. Houlden. Pp. 214-16. London: SCM Press.

— 1992. Catalogue of the Cuneiform Tablets in the Kouyunjik Collection of the British Museum: Third Supplement. London: British Museum Press.

— 1998a. The Qualifications of Babylonian Diviners. In: tikip santakki mala bašmu.... Festschrift für Rykle Borger zu seinem 65. Geburtstag am 24. Mai 1994, ed. S. M. Maul. CM no. 10. Pp. 141-58. Groningen: Styx. 1998b. Technical Terminology for Creation in the Ancient Near East. In: Intellectual Life of the Ancient Near East. Papers Presented at the 43rd Rencontre assyriologique internationale, ed. J. Prosecký. Pp. 189-93. Prague: Academy of Sciences of the Czech Republic, Oriental Institute.

2002. A literary citation. NABU 2002/12.

2007. Babylonian Oracle Questions. MC no. 13. Winona Lake: Eisenbrauns.

2013. Babylonian Creation Myths. MC no. 16. Winona Lake: Eisenbrauns.

Landsberger, B.

— 1939. Die babylonischen Termini für Gesetz und Recht. In: Symbolae ad iura Orientis antiqui pertinentes Paulo Koschaker dedicatae, ed. T. Folkers, J. Friedrich and J. G. Lautner. Pp. 219-34. Leiden: Brill.

Litke, R. L.

1998. A Reconstruction of the Assyro-Babylonian God-Lists. AN : ${ }^{d}$ a-nu-um and AN : Anu šá amēli. TBC no. 3. New Haven: Yale Babylonian Collection.

Matini, G., and Ambos, C.

— 2009. "Sono sono un bue..." Riflessioni sulle Preghiere di Lamento e di Espiazione nel Vicino Oriente Antico. In: Dallo Stirone al Tigri, dal Tevere all'Eufrate. Studi in onore di Claudio Saporetti, ed. P. Negri Scafa and S. Viaggio. Pp. 253-64. Roma: Aracne.

Mayer, W. R.

— 1976. Untersuchungen zur Formensprache der babylonischen "Gebetsbeschwörungen”. StPohl SM no. 5. Roma: Pontificium Institutum Biblicum.

1990. Sechs Šu-ila-Gebete. OrNS 59: 449-90.

Michalowski, P. 2006. The Strange History of Tumal. In: Approaches to Sumerian Literature. Studies in Honour of Stip (H. L.J. Vanstiphout), ed. P. Michalowski and N. Veldhuis. CM no. 35. Pp. 145-65. Leiden, Boston: Brill.

Oppenheim, A. L.

1956. The Interpretation of Dreams in the Ancient Near East. With a Translation of an Assyrian DreamBook. Transactions of the American Philosophical Society no. 46. Philadelphia: American Philosophical Society.

— 1974. A Babylonian Diviner's Manual. JNES 33: 197-220.

Parpola, S.

1983. Letters from Assyrian Scholars to the Kings Esarhaddon and Assurbanipal. Part II: Commentary and Appendices. AOAT no. 5/2. Neukirchen-Vluyn: Butzon \& Bercker.

— 1987. The Forlorn Scholar. In: Language, Literature, and History: Philological and Historical Studies Presented to Erica Reiner, ed. F. Rochberg-Halton. Pp. 257-78. New Haven: American Oriental Society.

Radner, K.

1997. Die neuassyrischen Privatrechtsurkunden als Quelle für Mensch und Umwelt. SAAS no. 6. Helsinki: The Neo-Assyrian Text Corpus Project.

Reiner, E.

1991. First-Millennium Babylonian Literature. In: The Assyrian and Babylonian Empires and other States of the Near East, from the Eighth to the Sixth Centuries B.C., ed. J. Boardman, J. E. S. Edwards, N. G. L. 
Hammond, W. Sommerfeld and C. B. F. Walker. Cambridge Ancient History no. III/2. Pp. $293-321$. Cambridge: Cambridge University Press.

Römer, W. H. P.

1986. Zukunftsdeutungen in sumerischen Texten. In: Religiöse Texte. Deutungen der Zukunft in Briefen, Orakeln und Omina, ed. O. Kaiser. TUAT no. II/1. Pp. 17-55. Gütersloh: Gütersloher Verlagshaus Mohn. Scurlock, J. A.

2011. Ritual "Rubbing” Recitations from Ancient Mesopotamia [Review of Böck 2007]. OrNS 80: 87-104. Schramm, W.

2008. Ein Compendium sumerisch-akkadischer Beschwörungen. GBAO no. 2. Göttingen: Universitätsverlag Göttingen.

Seux, M.-J.

- 1981. Šiggayyôn = šigû ? In: Mélanges bibliques et orientaux en l'honneur de M. Henri Cazelles, ed. Stol, M. A. Caquot and M. Delcor. AOAT no. 212. Pp. 419-38. Kevelaer: Butzon \& Bercker.

- 1986. Blindness and Night-Blindness in Akkadian. JNES 45: 295-99.

- 2006. The Digestion of Food According to Babylonian Sources. In: Médecine et médecins au Proche-Orient ancien, ed. L. Battini and P. Villard. BAR International Series no. 1528. Pp. 103-19. Oxford: British Archaeological Reports.

2007. Fevers in Babylonia. In: Disease in Babylonia, ed. I. L. Finkel and M. J. Geller. CM no. 36. Pp. 1-39. Leiden, Boston: Brill.

van der Toorn, K.

1985. Sin and Sanction in Israel and Mesopotamia. A Comparative Study. SSN no. 22. Assen/Maastricht: Van Gorcum.

Williams, C.

2002. Signs from the Sky, Signs from the Earth: The Diviner's Manual Revisited In: Under One Sky. Astronomy and Mathematics in the Ancient Near East, ed. J. M. Steele and A. Imhausen. AOAT no. 297. Pp. 473-85. Münster: Ugarit -Verlag.

Wiseman, D. J., and Black, J. A.

1995. Literary Texts from the Temple of Nabû. CTN no. 4. Oxford: British School of Archaeology in Iraq. Zimmern, $\mathrm{H}$.

— 1901. Beiträge zur Kenntnis der babylonischen Religion. Leipzig: Hinrichs.

Enrique Jiménez

Department of Near Eastern Languages \& Civilizations

Yale University

P.O. Box 208236

New Haven,

CT 06520-8236

enrique.jimenez@yale.edu

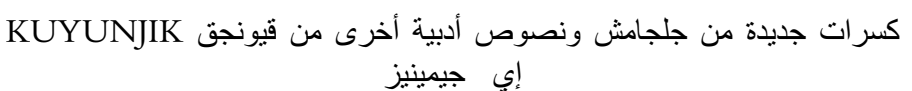

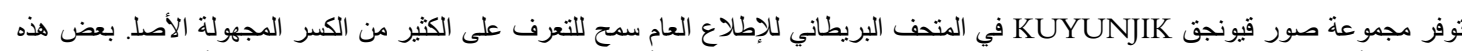

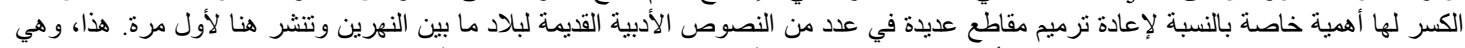

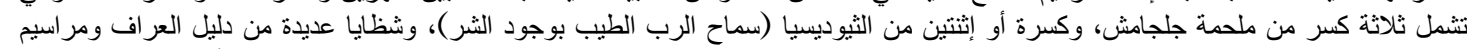

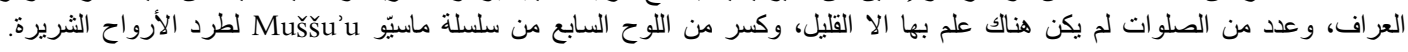

